Florida International University

FIU Digital Commons

FIU Electronic Theses and Dissertations

University Graduate School

6-27-2017

\title{
The Effect of Vitamin D3 Supplementation on Kidney Function and Cardiovascular Disease Markers among Hispanics and African Americans with Type 2 Diabetes
}

Gustavo G. Zarini

Florida International University, gzari001@fiu.edu

DOI: $10.25148 /$ etd.FIDC001960

Follow this and additional works at: https://digitalcommons.fiu.edu/etd

Part of the Cardiovascular Diseases Commons, Dietetics and Clinical Nutrition Commons, Endocrine System Diseases Commons, $\underline{\text { Human and Clinical Nutrition Commons, Nutritional and }}$ Metabolic Diseases Commons, and the Nutritional Epidemiology Commons

\section{Recommended Citation}

Zarini, Gustavo G., "The Effect of Vitamin D3 Supplementation on Kidney Function and Cardiovascular Disease Markers among Hispanics and African Americans with Type 2 Diabetes" (2017). FIU Electronic Theses and Dissertations. 3376.

https://digitalcommons.fiu.edu/etd/3376 


\title{
FLORIDA INTERNATIONAL UNIVERSITY \\ Miami, Florida
}

\section{THE EFFECT OF VITAMIN D3 SUPPLEMENTATION ON KIDNEY FUNCTION AND CARDIOVASCULAR DISEASE MARKERS AMONG HISPANICS AND AFRICAN AMERICANS WITH TYPE 2 DIABETES}

\author{
A dissertation submitted in partial fulfillment of \\ the requirements for the degree of \\ DOCTOR OF PHILOSOPHY \\ in \\ DIETETICS AND NUTRITION \\ by \\ Gustavo G. Zarini
}


To: Dean Tomás R. Guilarte

R.Stempel College of Public Health and Social Work

This dissertation, written by Gustavo G. Zarini, and entitled The Effect of Vitamin D3 Supplementation on Kidney Function and Cardiovascular Disease Markers among Hispanics and African Americans with Type 2 Diabetes, having been approved in respect to style and intellectual content, is referred to you for judgment.

We have read this dissertation and recommend that it be approved.

Adriana Campa

Tan Li

Juan P. Liuzzi

Fatma G. Huffman, Major Professor

Date of Defense: June 27, 2017

The dissertation of Gustavo G. Zarini is approved.

Dean Tomás R. Guilarte R.Stempel College of Public Health and Social Work

Florida International University, 2017 
(C) Copyright 2017 by Gustavo G. Zarini

All rights reserved. 


\section{DEDICATION}

I dedicate this dissertation to my father and mother, Jorge Ernesto and Matilde, for their unconditional love, support, and motivation, to complete my doctoral studies. Their stability and sacrifices gave me strength to make it this far. I also dedicate this dissertation to my brother, Jorge Ernesto, for his tolerance and support throughout this process. 


\section{ACKNOWLEDGMENTS}

I would like to thank my committee members for their valuable time, support and guidance throughout this research and dissertation. I am very appreciative to Dr. Fatma G. Huffman, my Major Professor and mentor, she had a major role during my dissertation and life. Her encouragement and efforts in making sure I succeeded are invaluable. Dr. Adriana Campa, thank you for providing me great advice, guidance and expertise during my doctoral degree. Thank you, Dr. Tan $\mathrm{Li}$, for your time and statistical advice. Dr. Juan P. Liuzzi, thank you for your support and guidance. 
ABSTRACT OF THE DISSERTATION

THE EFFECT OF VITAMIN D3 SUPPLEMENTATION ON KIDNEY FUNCTION

AND CARDIOVASCULAR DISEASE MARKERS AMONG HISPANICS AND

AFRICAN AMERICANS WITH TYPE 2 DIABETES

by

Gustavo G. Zarini

Florida International University, 2017

Miami, Florida

Professor Fatma G. Huffman, Major Professor

Serum vitamin D deficiency/insufficiency, Chronic Kidney Disease (CKD) and elevated blood pressure are important health concerns especially among minorities with type 2 diabetes. The effect of vitamin $D_{3}$ supplementation (cholecalciferol) at 6,000 IU/day (d) vs. 4,000 IU/d on kidney function and cardiovascular disease markers among Hispanics and African Americans with type 2 diabetes and hypovitaminosis $D(<30 \mathrm{ng} / \mathrm{ml})$ was evaluated. Subjects $(n=63)$ were recruited from two clinics in Miami-Dade County, FL. Fasting venous blood and fresh, single-voided first morning urine samples were collected from each participant by a certified phlebotomist and analyzed by Solstas Lab Partners, Davie, FL. Linear mixed models were used to compare the interaction between time and intervention. Least Significant Difference (LSD) comparisons were used to detect significant differences within and between 4,000 IU/d and 6,000 IU/d groups from baseline, 3 and 6 months. In the 4,000 IU/d and 6,000 IU/d groups, a significant increase in serum 25-hydroxy vitamin $D[25(\mathrm{OH}) \mathrm{D}]$ 
levels were observed from baseline $[(19.9 \pm 1.1 \mathrm{ng} / \mathrm{mL})$ and $(21.4 \pm 1.3 \mathrm{ng} / \mathrm{mL})]$ to 3 months [(36.1 $\pm 2.2 \mathrm{ng} / \mathrm{mL}, \mathrm{p}<.001)$ and $(43.0 \pm 2.7 \mathrm{ng} / \mathrm{mL}, \mathrm{p}<0.001)]$; and 6 months [(37.1 $\pm 2.4 \mathrm{ng} / \mathrm{mL}, \mathrm{p}<0.001)$ and $(39.2 \pm 3.0 \mathrm{ng} / \mathrm{mL}, \mathrm{p}<0.001)]$, respectively. Significant increase in estimated Glomerular Filtration Rate (eGFR) creatinine equation values were observed from baseline $(81.2 \pm 3.0 \mathrm{~mL} / \mathrm{min})$ to 6 months $(90.2 \pm 2.8 \mathrm{~mL} / \mathrm{min}, \mathrm{p}<0.001)$ in the $4,000 \mathrm{IU} / \mathrm{d}$ group. Significant decrease in eGFR creatinine - cystatin C equation values were found from 3 months $(109.2 \pm 3.9 \mathrm{~mL} / \mathrm{min})$ to 6 months $(100.9 \pm 3.7 \mathrm{~mL} / \mathrm{min}, \mathrm{p}=0.006)$ in the $4,000 \mathrm{IU} / \mathrm{d}$ group. Systolic blood pressure levels significantly decreased from baseline $(144.1 \pm 4.0 \mathrm{mmHg})$ to 6 months $(134.5 \pm 3.5 \mathrm{mmHg}, \mathrm{p}=0.020)$ only for the 6,000 IU/d group. Supplementation with vitamin $\mathrm{D}_{3}$ longer than 6 months may be needed to determine sustained long term effects in kidney and cardiovascular disease markers. Further research could provide more information for translation of these findings into recommendations for individuals with CKD, hypertension and type 2 diabetes. The efficacy of vitamin $D_{3}$ supplementation as complementary therapy for CKD and blood pressure in minority and other ethnic groups needs further investigation in larger and longer duration randomized controlled trials. 


\section{TABLE OF CONTENTS}

CHAPTER

PAGE

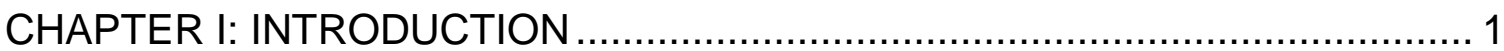

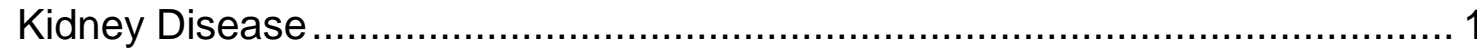

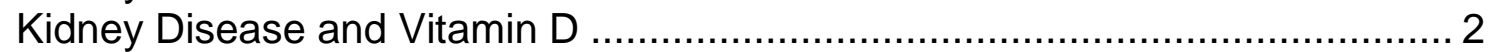

Kidney Disease and Vitamin D Supplementation......................................... 4

Blood Pressure and Vitamin D ............................................................. 5

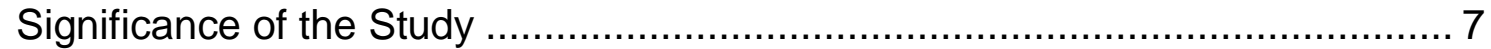

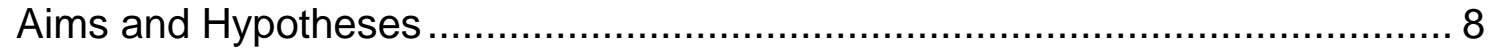

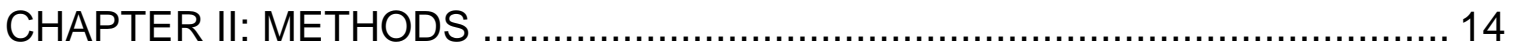

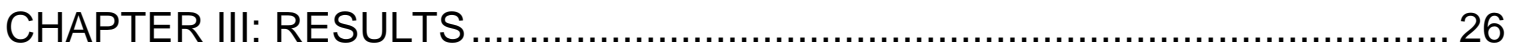

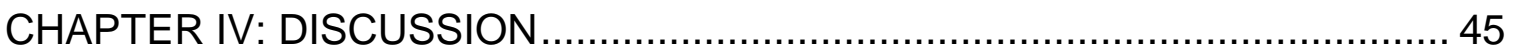

CHAPTER V: SUMMARY AND CONCLUSIONS ........................................... 59

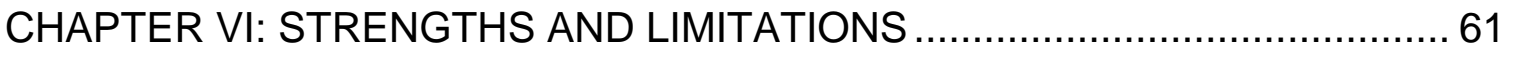

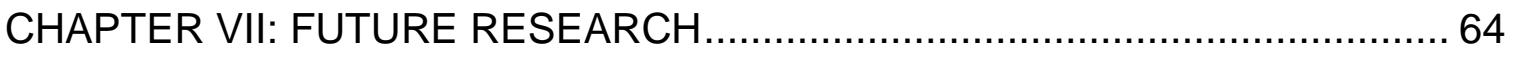

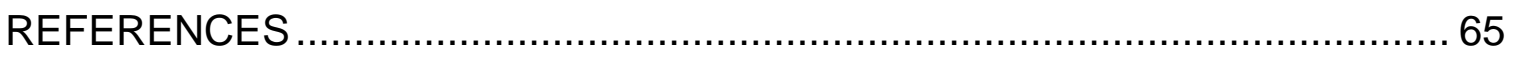

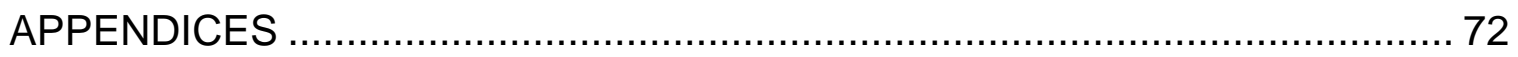

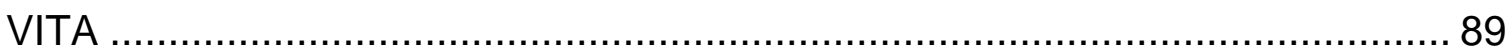




\section{LIST OF TABLES}

TABLE

PAGE

CHAPTER I

Table 1. Summary of Aims, Hypotheses and Statistical Analyses 10

CHAPTER II

Table 1. Assessments Frequency...................................................18

Table 2. Outcomes Power Calculation................................................25

CHAPTER III

Table 1. Baseline Comparisons of Vitamin D3 Intervention Groups ..............27

Table 2. Paired Comparisons of Vitamin D3 at 4,000 IU from Pre- to PostIntervention.

Table 3. Paired Comparisons of Vitamin D3 at 6,000 IU from Pre- to PostIntervention

Table 4. Unadjusted and Adjusted Intervention Groups Comparisons of 25(OH)D at Different Time Points

Table 5. Unadjusted and Adjusted Intervention Groups Comparisons of CKD-EPI creatinine at Different Time Points.

Table 6. Unadjusted and Adjusted Intervention Groups Comparisons of CKD-EPI creatinine - cystatin C at Different Time Points.

Table 7. Unadjusted and Adjusted Intervention Groups Comparisons of Microalbuminuria at Different Time Points

Table 8. Unadjusted and Adjusted Intervention Groups Comparisons of Blood Pressure at Different Time Points. 


\section{ABBREVIATIONS AND ACRONYMS}

$\begin{array}{ll}\text { 25(OH)D } & \text { 25-hydroxy vitamin D } \\ \text { A1C } & \text { Hemoglobin A1c } \\ \text { B } & \text { Baseline } \\ \text { BMI } & \text { Body Mass Index } \\ \text { CDC } & \text { Centers for Disease Control and Prevention } \\ \text { CKD } & \text { Chronic Kidney Disease } \\ \text { CKD-EPI } & \text { Chronic Kidney Disease Epidemiology Collaboration } \\ \text { DBP } & \text { Diastolic Blood Pressure } \\ \text { DSMB } & \text { Data Safety Monitoring Board } \\ \text { DV } & \text { Dependent Variable } \\ \text { eGFR } & \text { Estimated Glomerular Filtration } \\ \text { ELISA } & \text { Enzyme-Linked ImmonoSorbent Assay } \\ \text { ESRD } & \text { End Stage Renal Disease } \\ \text { FFQ } & \text { Food Frequency Questionnaire } \\ \text { FPG } & \text { Fasting Plasma Glucose } \\ \text { HMO } & \text { Health Maintenance Organization } \\ \text { Hs-CRP } & \text { High-sensitivity C-reactive Protein } \\ \text { IOM } & \text { Institute of Medicine } \\ \text { IRB } & \text { Institutional Review Board } \\ \text { IV } & \text { Independent Variable } \\ \text { KDIGO } & \text { Kidney Disease Improving Global Outcomes } \\ & \end{array}$




$\begin{array}{ll}\text { KDOQI } & \text { Kidney Disease Outcomes Quality Initiative } \\ \text { LSD } & \text { Least Significant Difference } \\ \text { MAU } & \text { Microalbuminuria } \\ \text { MDRD } & \text { Modification of Diet in Renal Disease } \\ \text { mmHg } & \text { Millimeter of Mercury } \\ \text { NHANES } & \text { National Health and Nutrition Examination Survey } \\ \text { PTH } & \text { Parathyroid Hormone } \\ \text { RAAS } & \text { Renin-Angiotensin-Aldosterone System } \\ \text { RDA } & \text { Recommended Dietary Allowance } \\ \text { S } & \text { Screening } \\ \text { SBP } & \text { Systolic Blood Pressure } \\ \text { SD } & \text { Standard Deviation } \\ \text { SE } & \text { Standard Error }\end{array}$




\section{CHAPTER I: INTRODUCTION}

\section{Kidney Disease}

Kidney disease is the ninth leading cause of death in the U.S. (National Center for Health Statistics, 2012) affecting 31 million (10\%) of American adults with the majority unaware of their conditions (CDC, 2011). Diabetes accounted for 44\% of the incidence of kidney failure in 2012 (American Kidney Fund, 2015). Furthermore, complications from kidney disease are more prevalent in minorities: End Stage Renal Disease (ESRD) was nearly 1.5 times more likely in Hispanics as compared to non-Hispanic Whites (CDC, 2012).

The Kidney Disease Improving Global Outcomes (KDIGO) guidelines (KDIGO, 2013) recommends using the Chronic Kidney Disease Epidemiology Collaboration (CKD-EPI) equation with serum creatinine for initial evaluation and staging of kidney disease. The Modification of Diet in Renal Disease (MDRD) equation may not be as reliable as the CKD-EPI equation for Glomerular Filtration Rate (GFR) levels between 60 and $90 \mathrm{~mL} / \mathrm{min} / 1.73 \mathrm{~m}^{2}$ (Levey et al., 2009). Although the CKD-EPI equation (eGFR creatinine) adjust for age, gender

and race, serum creatinine is affected by variations in diet and lean muscle mass (National Kidney Foundation, 2009). Cystatin C, a 13-kDa, single-chain amino acid present in almost all nucleated cells (Abrahamson et al., 1990), has been proposed as a confirmatory marker to add to the CKD-EPI equation, alone (eGFR cystatin) or with serum creatinine (eGFR creatinine- cystatin C), when eGFR creatinine is assumed inaccurate (KDIGO, 2013). 
Microalbuminuria is considered an early biomarker for loss of kidney function. Microalbuminuria a sensitive marker recommended by the Kidney Disease Outcomes Quality Initiative (KDOQI) Clinical Practice guidelines to be used to assess and monitor kidney function in early stages of kidney disease (KDOQI, 2000). Reported in previous studies, microalbuminuria was associated with cardiovascular disease and mortality in individuals with type 2 diabetes (Mogensen, 1984; Valmadrid et al., 2000). The American Diabetes Association recommends that individuals with type 2 diabetes be tested for microalbuminuria at the diagnosis of diabetes and subsequently every year (American Diabetes Association, 2009). Decrease in microalbuminuria values represents an improvement in kidney function and possible reduction in cardiovascular disease risk (KDOQI, 2000).

\section{Kidney Disease and Vitamin D}

The prevalence of chronic kidney disease (CKD) and hypovitaminosis $D$ disproportionately affects minorities and individuals with type 2 diabetes (Diaz et al., 2009; Melamed et al., 2009; Zadshir et al., 2005). Data from the National Health and Nutrition Examination Survey (NHANES) indicated that cases of kidney disease were distributed disproportionally among Hispanics, with Hispanics presenting the highest proportion of kidney disease (38.5\%), followed by non-Hispanic Blacks (36.2\%) and non-Hispanic Whites (27.8\%) (Diaz et al., 2009). Vitamin D status differ across ethnic groups. Non-Hispanic Blacks and Hispanics have higher rates ( $80.4 \%$ and $59.0 \%$ ) of serum 25 -hydroxy vitamin D 
[25(OH)D] levels considered deficient as compared to Whites $(39.5 \%, p<0.01)$

(Diaz et al., 2009). Individuals with kidney disease had higher rates of serum vitamin D deficiency (53.2\%) as compared to those with normal kidney function (47.0\%) (Diaz et al., 2009). Individuals with kidney disease were shown to have hypovitaminosis D even in the early stages of kidney disease (Lee et al., 2010). Moreover, since their kidneys are deteriorated, the ability to activate adequate amounts of vitamin $\mathrm{D}$ decline. Reduction in renal function over a 4-year period was greater for individuals with insufficient serum 25(OH)D and diabetes in Caucasian adults as compared to controls (de Boer et al., 2011). In a 5-year follow-up study of a random sample of Caucasians $(n=4,330)$, aged $30-60$ years, low 25(OH)D levels predicted higher protein excretion (Skaaby et al., 2013). Serum $25(\mathrm{OH})$ D levels have been inversely associated with albuminuria in a U.S. representative population and this association remained after controlling for diabetes (de Boer et al., 2007).

Insufficient dietary and serum 25(OH)D levels could contribute to morbidity and mortality (Heaney et al., 2005; Zimmermann \& Gummert, 2010). In the longitudinal study by Pilz et al. (2011), with a median follow-up time of 9.4 years, the risk of mortality in 444 individuals with CKD (stages 3-5) was higher in those with serum vitamin $\mathrm{D}$ deficiency as compared to those with normal vitamin $\mathrm{D}$ status (hazard ratios: $4.38,95 \% \mathrm{Cl} 2.13-9.00$ ). The mechanism that could explain the association between vitamin D status and mortality; however, remains unknown. Sufficient levels of serum $25(\mathrm{OH}) \mathrm{D}$ are protective of the renal 
and cardiovascular systems; conversely, hypovitaminosis D may accelerate disease progression (Judd and Tangpricha, 2008; Li, 2012).

\section{Kidney Disease and Vitamin D Supplementation}

Supplementation that raises serum 25(OH)D levels has been recommended to prevent health problems in adults (Heaney et al., 2005; Williams, et al., 2009). Investigations of the effect of vitamin $\mathrm{D}_{3}$ supplementation on minorities with type 2 diabetes; however, have been limited. Most vitamin D supplementation trials in patients with kidney disease have been conducted primarily in Caucasians without diabetes. Vitamin $\mathrm{D}_{3}$ supplementation at high doses [>2000 IU/day (d)] has promise for achieving vitamin D sufficiency for persons with CKD (Alvarez et al., 2012). On the other hand, studies concerning vitamin $D_{2}$ supplementation and vitamin D status in kidney disease were less conclusive (Alvarez et al., 2012). Vitamin $D_{3}$ may provide a safer and more cost-effective strategy for the treatment of early CKD than oral vitamin $\mathrm{D}_{2}$ or synthetic analogues. There are some studies available on vitamin $D_{3}$ supplementation in adults, in which kidney function was measured (Kim et al., 2011; Rucker et al., 2009; Molina et al., 2014). Vitamin $D_{3}$ supplementation, provided according to the participant's vitamin $D$ status, for 4 months showed a reduction of albuminuria, but no change in GFR for ethnically diverse (43\% Caucasian, 22\% Black, and 45\% Asian) patients ( $n=63$ ) with CKD stages 2-4 and hypovitaminosis D (Kim et al., 2011). Supplementation of $1000 \mathrm{IU} /$ daily of vitamin $\mathrm{D}_{3}$ among 128 Canadian adults with later stages of kidney disease (stages 3-5) found no improvements in kidney 
function (GFR) compared with a control group; however, supplementation was of short duration (3 months) and mean 25(OH)D levels were below vitamin $\mathrm{D}$ sufficiency (30 ng/mL) by the end of the study (Rucker et al., 2009).

Supplementation of vitamin $D_{3}$ at $666 \mathrm{IU} / \mathrm{d}$ for 6 months significantly lowered albuminuria in a Caucasian older adult cohort $(n=101)$ with CKD stages $3-4$, but no significant improvements were found for estimated GFR (Molina et al., 2014). Early supplementation with vitamin $\mathrm{D}_{3}$ might provide a more valuable treatment and possibly delay adverse kidney disease outcomes.

\section{Blood Pressure and Vitamin D}

The Centers for Disease Control and Prevention (CDC) indicated that one in 3 individuals living in the U.S., an estimated 70 million adults, have high blood pressure $(C D C, 2015)$ which place them at higher risk to die from heart disease (Nwankwo et al., 2013). The CDC recommended decreasing individual's systolic blood pressure by 12 to $13 \mathrm{mmHg}$ because it could potentially reduce deaths from cardiovascular disease by $25 \%$. Still, high levels of blood pressure among Hispanics and Blacks continue to be a challenge (CDC, 2013).

Serum vitamin D deficiency/insufficiency and elevated blood pressure are important health concerns especially among minorities. Available evidence from observational studies indicated that low $25(\mathrm{OH}) \mathrm{D}$ levels are related to elevated blood pressure. A study by Schmitz et al. (2009) conducted in Hispanics and African Americans $(n=1334)$ found an inverse association between 25(OH)D 
levels and blood pressure, after adjusting for age, gender, ethnicity and seasons. When BMI was included in the final model, blood pressure was no longer associated with $25(\mathrm{OH})$ D levels. In this study, only a small proportion of subjects had systolic blood pressure $\geq 140 \mathrm{mmHg}(\mathrm{n}=72 ; 5 \%)$ and diastolic blood pressure $\geq 90 \mathrm{mmHg}(\mathrm{n}=93 ; 7 \%)$. Data from NHANES that included 12,644 individuals $\geq 20$ years old showed that after adjusting for age, gender, ethnic background, and physical activity, 25(OH)D levels were inversely linked with blood pressure (Scragg et al., 2007). When the highest quintile of 25(OH)D ( $\geq 87$ $\mathrm{nmol} / \mathrm{L})$ was compared to the lowest quintile $(40.4 \mathrm{nmol} / \mathrm{L})$, both mean systolic blood pressure and diastolic blood pressure were $3.0 \mathrm{mmHg}$ and $1.6 \mathrm{mmHg}$ lower in those in the highest quintile (Scragg et al., 2007). As in the study by Schmitz et al. (2009), addition of BMI as an adjustment variable in the model weakened the relationship between $25(\mathrm{OH}) \mathrm{D}$ and blood pressure levels. In the study by Scragg et al. (2007), systolic blood pressure continued to be significant despite adjustment. Likewise, Forman et al. (2007) found an inverse association between 25(OH)D and incident risk of hypertension by exploring two cohorts (men=613) from the Health Professionals' Follow-up Study and Nurses' Health Study (women=1198) ages 40-75.

In contrast with the findings from observational studies, the relationship between vitamin $D_{3}$ supplementation and its effect on blood pressure is not as clear. Clinical trials and meta-analyses have tried to elucidate the relationship between vitamin $D$ supplementation and blood pressure; however, findings from 
these studies are inconsistent. Results from some clinical trials and metaanalysis were not able to determine significant reductions in blood pressure levels (Pittas et al., 2010; Witham et al., 2009; Jorde et al., 2010; Beveridge et al., 2015; Larsen et al., 2012) while other investigations did find significant improvements in blood pressure (Witham et al., 2010; Forman et al., 2013; Pfeifer et al., 2001; Sugden et al., 2008). The mechanism of how vitamin D affects blood pressure is poorly understood. Nonetheless, it has been postulated that vitamin D could affect blood pressure regulation through the ReninAngiotensin-Aldosterone System (RAAS) (Li et al., 2004; Pilz et al., 2009).

Deficient/insufficient 25(OH)D levels could be corrected by vitamin $\mathrm{D}_{3}$ supplementation which may be of significance and have a potential impact on health of minority groups with type 2 diabetes. Furthermore, improving blood pressure levels using vitamin $D_{3}$ may prevent future complications associated with kidney and cardiovascular disease. The clinical importance of vitamin $D_{3}$ supplementation as adjunct therapy is to prevent kidney and cardiovascular disease complications.

\section{Significance of the Study}

Even though hypovitaminosis $\mathrm{D}$, type 2 diabetes, kidney disease and cardiovascular disease are major health problems affecting minorities, no study so far has investigated the effect of two high doses of vitamin $D_{3}$ supplementation (4,000 IU/d and 6,000 IU/d) exclusively among Hispanics and 
African Americans with type 2 diabetes and hypovitaminosis D. Supplementation with vitamin $D_{3}$ may have the potential of delaying and managing the progression of CKD and cardiovascular disease. As an inexpensive and safe supplement, vitamin $\mathrm{D}_{3}$ (cholecalciferol) could have significant benefit in reducing diabetes complications and health disparities among Hispanics and African Americans with type 2 diabetes.

\section{Aims and Hypotheses}

Aim 1: To evaluate the effect of vitamin $\mathrm{D}_{3}$ supplementation (cholecalciferol) at 6,000 IU/d vs. 4,000 IU/d on kidney function among Hispanics and African Americans with type 2 diabetes and hypovitaminosis $D(<30 \mathrm{ng} / \mathrm{ml})$.

Hypothesis 1: Vitamin $D_{3}$ supplementation at $6,000 \mathrm{IU} / \mathrm{d}$ will be more effective in raising 25-hydroxy vitamin $D[25(\mathrm{OH}) \mathrm{D}]$ levels from deficient/insufficient to sufficient as compared to $4,000 \mathrm{IU} / \mathrm{d}$ over 6 months.

Hypothesis 2: Vitamin $D_{3}$ supplementation at 6,000 lU/d will be more effective in increasing estimated glomerular filtration rate (eGFR) using CKD-EPI creatinine equation (Chronic Kidney Disease Epidemiology Collaboration) when compared to $4,000 \mathrm{IU} / \mathrm{d}$ over 6 months.

Hypothesis 3: Vitamin $D_{3}$ supplementation at 6,000 lU/d will be more effective in increasing eGFR using CKD-EPI creatinine - cystatin C equation (Chronic Kidney Disease Epidemiology Collaboration) when compared to 4,000 IU/d over 6 months. 
Hypothesis 4: Vitamin $D_{3}$ supplementation at 6,000 IU/d will be more effective than the $4,000 \mathrm{IU} / \mathrm{d}$ over 6 months in lowering microalbuminuria measured by first morning urine samples.

Aim 2: To evaluate the effect of vitamin $D_{3}$ supplementation at $6,000 \mathrm{IU} / \mathrm{d}$ vs. 4,000 IU/d on markers of cardiovascular disease risk among Hispanics and African Americans with type 2 diabetes and hypovitaminosis $D(<30 \mathrm{ng} / \mathrm{ml})$. Hypothesis 1: Vitamin $\mathrm{D}_{3}$ supplementation at 6,000 lU/d will be more effective than the 4,000 IU/d over 6 months in lowering systolic and diastolic blood pressure levels. 
Table 1: Summary of Aims, Hypotheses and Statistical Analyses

\begin{tabular}{|c|c|c|c|c|}
\hline Aims & Hypotheses & $\begin{array}{c}\text { Dependent \& } \\
\text { Independent } \\
\text { Variables }\end{array}$ & $\begin{array}{l}\text { Controlled } \\
\text { Variables }\end{array}$ & $\begin{array}{l}\text { Statistical } \\
\text { Analysis }\end{array}$ \\
\hline $\begin{array}{l}\text { Aim 1: To evaluate the } \\
\text { effect of vitamin } D_{3} \\
\text { supplementation } \\
\text { (cholecalciferol) at } \\
6,000 \text { IU/d vs. 4,000 } \\
\text { IU/d on kidney function } \\
\text { among Hispanics and } \\
\text { African Americans with } \\
\text { type } 2 \text { diabetes and } \\
\text { hypovitaminosis } D \\
\text { (<30 ng/ml). }\end{array}$ & $\begin{array}{l}\text { Hypothesis 1: Vitamin } D_{3} \\
\text { supplementation at } 6,000 \mathrm{lU} / \mathrm{d} \\
\text { will be more effective in raising } \\
25 \text {-hydroxy vitamin } \mathrm{D} \\
\text { [25(OH)D] levels from } \\
\text { deficient/insufficient to } \\
\text { sufficient as compared to } \\
4,000 \mathrm{IU} / \mathrm{d} \text { over } 6 \text { months. }\end{array}$ & $\begin{array}{l}\text { H1 - } \\
\text { DV: DV: } \\
\text { 25(OH)D } \\
\text { IV: vitamin D3 } \\
\text { supplementation }\end{array}$ & $\begin{array}{l}\text { Age gender, } \\
\text { BMI, known } \\
\text { years with } \\
\text { diabetes, A1c, } \\
\text { diabetes } \\
\text { medications, } \\
\text { blood pressure } \\
\text { medications, } \\
\text { vitamin D } \\
\text { intake, sun } \\
\text { exposure. }\end{array}$ & $\begin{array}{l}\text { All data analyses } \\
\text { for the study was } \\
\text { conducted on an } \\
\text { "intent to treat" } \\
\text { basis. Normal } \\
\text { distribution of all } \\
\text { variables was } \\
\text { assessed. } \\
\text { Independent t- } \\
\text { test (parametric) } \\
\text { or Mann-Whitney } \\
\text { U-test }\end{array}$ \\
\hline
\end{tabular}




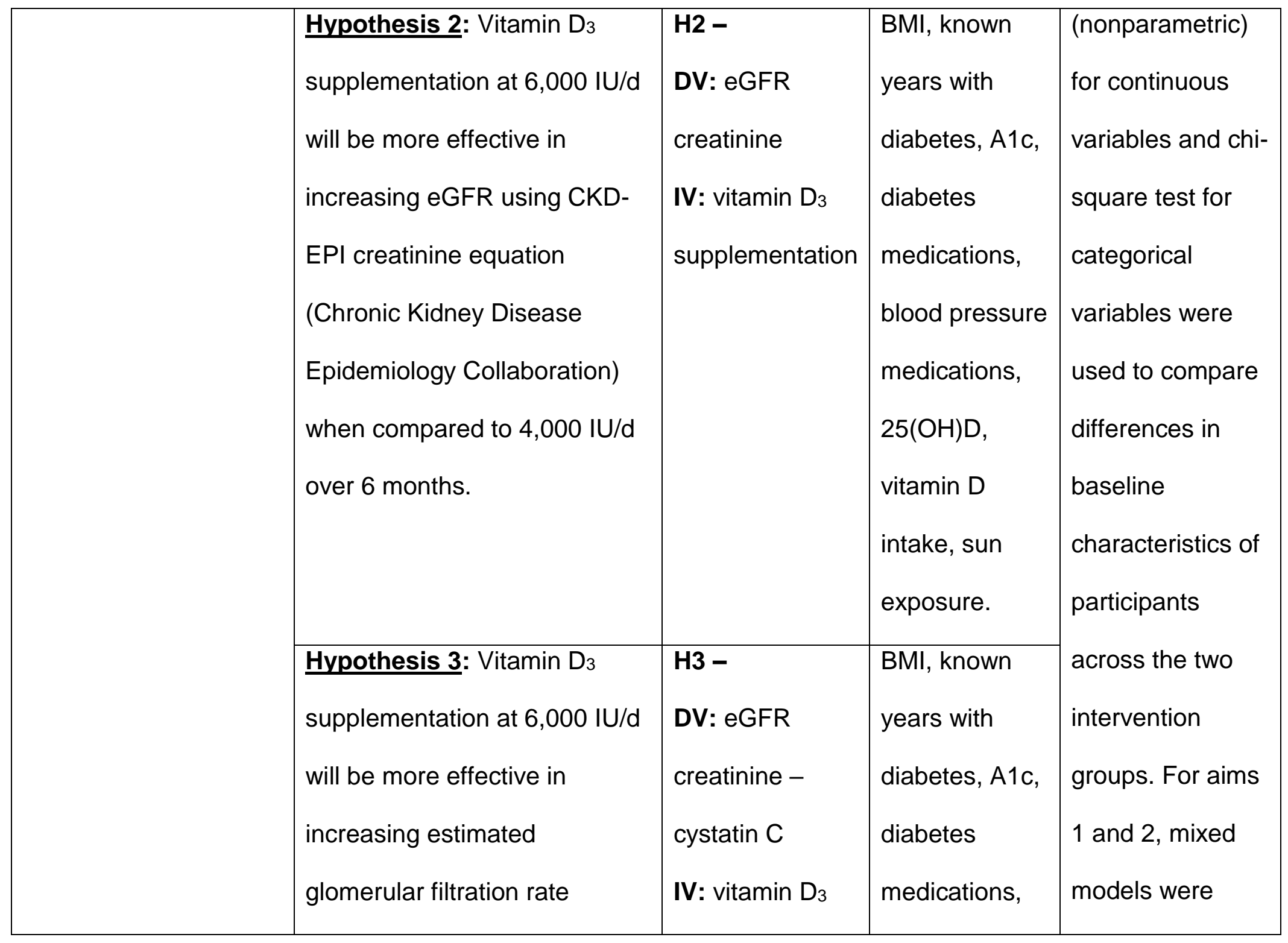




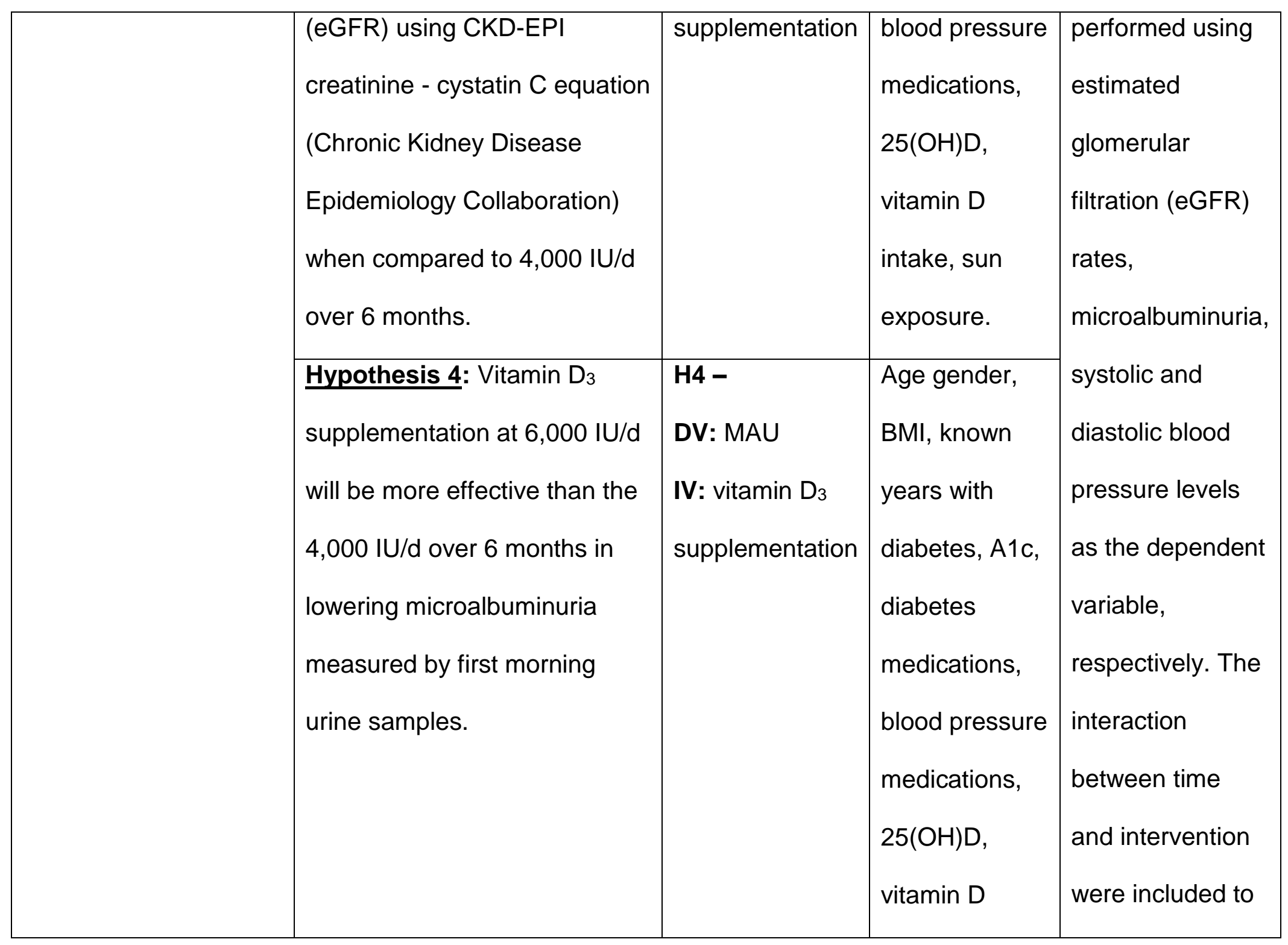




\begin{tabular}{|c|c|c|c|c|}
\hline & & & $\begin{array}{l}\text { intake, sun } \\
\text { exposure. }\end{array}$ & $\begin{array}{l}\text { evaluate the } \\
\text { dosage effect on }\end{array}$ \\
\hline $\begin{array}{l}\text { Aim 2: To evaluate the } \\
\text { effect of vitamin } D_{3} \\
\text { supplementation at } \\
6,000 \mathrm{IU} \text { vs. } 4,000 \mathrm{IU} / \mathrm{d} \\
\text { on markers of } \\
\text { cardiovascular disease } \\
\text { among Hispanics and } \\
\text { African Americans with } \\
\text { type } 2 \text { diabetes and } \\
\text { hypovitaminosis } D \\
\text { (<30 } \mathrm{ng} / \mathrm{ml}) \text {. }\end{array}$ & $\begin{array}{l}\text { Hypothesis 1: Vitamin } \mathrm{D}_{3} \\
\text { supplementation at } 6,000 \mathrm{IU} / \mathrm{d} \\
\text { will be more effective than the } \\
4,000 \mathrm{IU} / \mathrm{d} \text { over } 6 \text { months in } \\
\text { lowering systolic and diastolic } \\
\text { blood pressure levels. }\end{array}$ & $\begin{array}{l}\text { H1 - } \\
\text { DV: SBP \& DBP } \\
\text { IV: vitamin } \mathrm{D}_{3} \\
\text { supplementation }\end{array}$ & $\begin{array}{l}\text { Age gender, } \\
\text { BMI, known } \\
\text { years with } \\
\text { diabetes, A1c, } \\
\text { diabetes } \\
\text { medications, } \\
\text { blood pressure } \\
\text { medications, } \\
25(\mathrm{OH}) \mathrm{D}, \\
\text { vitamin D } \\
\text { intake, sun } \\
\text { exposure. }\end{array}$ & $\begin{array}{l}\text { the change of the } \\
\text { dependent } \\
\text { variable over } \\
\text { time. }\end{array}$ \\
\hline
\end{tabular}




\section{CHAPTER II: METHODS}

The clinical trial conducted by our laboratory entitled "The effect of vitamin D supplementation on cardiovascular risk factors among Hispanics and African Americans with type 2 diabetes" was approved by the Institutional Review Board (IRB) at Florida International University (IRB Protocol Approval \#: IRB-13-0155).

\section{Recruitment of Subjects}

Subjects were recruited from two clinics in Miami-Dade County, Florida (Borinquen Health Care Center and Clinical Care Medical Center) from July 2011 to March 2013 using flyers explaining the purpose of the study, inclusion/exclusion criteria and containing investigators' emails and phone numbers. The non-randomized study screened subjects based on the inclusion/ exclusion criteria described as follows:

\section{Inclusion criteria:}

- Serum vitamin D insufficiency $[25(\mathrm{OH}) \mathrm{D}<30 \mathrm{ng} / \mathrm{ml}]$;

- Age 30-70 years old;

- Hispanic or African American; and

- Having type 2 diabetes

\section{Exclusion criteria:}

- Taking vitamin D supplements other than standard multivitamin formula;

- Pregnant or lactating;

- Kidney disease (glomerular filtration rate lower than $30 \mathrm{ml} / \mathrm{min} / 1.73 \mathrm{~m}^{2}$, stages 4-5) and kidney failure (defined as currently on dialysis). 
- Using insulin to manage blood glucose;

- Major psychiatric disorders;

- Cancer;

- HIV/AIDS; and

- Hepatitis

\section{Enrollment and Intervention}

All subjects signed an informed consent in Spanish or English based on their preference prior to participation in the study. Participants in both intervention groups were required to take either $4,000 \mathrm{IU}$ or $6,000 \mathrm{IU}$ of vitamin $\mathrm{D}_{3}$ given in the form of a pill in a single daily dose. Subjects in the 4,000 IU/d group were recruited first and intervention was provided. Subjects were included on a first come, first served basis until the required calculated sample size was attained. After recruitment for the $4,000 \mathrm{IU} / \mathrm{d}$ group was completed, we conducted the recruitment for the 6,000 IU/d group. Hence, group selection was not conducted randomly and did not run in parallel. The number of subjects in the $6,000 \mathrm{IU} / \mathrm{d}$ group was reduced to the minimum sample size required to find significant differences in the main outcome variables.

Ninety-two participants were screened $[4,000 \mathrm{IU} / \mathrm{d}$ group $(n=63)$ and 6,000 IU/d group $(n=29)]$. Sixty-three qualified for the study and were enrolled for the vitamin $\mathrm{D}_{3}$ intervention [4,000 IU/d group $(\mathrm{n}=39)$ and $(6,000 \mathrm{IU} / \mathrm{d}(\mathrm{n}=24)]$. Four participants were lost to follow-up after baseline [4,000 IU/d group $(n=1)$ and 
$6,000 \mathrm{IU} / \mathrm{d}$ group ( $\mathrm{n}=3$ )]. Additionally, two participants were lost to follow-up after the 3 months' assessment in the 6,000 IU/d group (Figure 1). Participants CKD stages at baseline: $(n=45,71.0 \%)$ CKD stage 1 ( $\geq 90$ eGFR $\left.\mathrm{ml} / \mathrm{min} / 1.73 \mathrm{~m}^{2}\right)$; $(\mathrm{n}=15,24 \%)$ CKD stage 2 (60-89 eGFR $\left.\mathrm{ml} / \mathrm{min} / 1.73 \mathrm{~m}^{2}\right) ;(\mathrm{n}=3,5.0 \%)$ CKD stage 3 (30-59 eGFR $\left.\mathrm{ml} / \mathrm{min} / 1.73 \mathrm{~m}^{2}\right)$. The study used an intent to treat approach, all 63 subjects were included in the statistical analysis. Each participant was seen 4 times during the study (screening, baseline, 3 and 6 months). Table 1 describes assessments and assays conducted at each visit. 
Figure 1. Flow Diagram Showing Recruitment and Follow-Up of Participants

\begin{tabular}{|c|c|c|c|c|c|}
\hline \multirow{2}{*}{\multicolumn{2}{|c|}{\begin{tabular}{|c|}
$4,000 \mathrm{IU} / \mathrm{d}$ \\
Screening $(\mathrm{n}=63)$
\end{tabular}}} & \multicolumn{2}{|c|}{$\begin{array}{c}\text { Excluded Due to Normal Levels } \\
\text { of } 25(\mathrm{OH}) \mathrm{D}(\mathrm{n}=27)\end{array}$} & \multirow{2}{*}{\multicolumn{2}{|c|}{$\begin{array}{c}6,000 \mathrm{IU} / \mathrm{d} \\
\begin{array}{c}\text { Screening } \\
(n=29)\end{array}\end{array}$}} \\
\hline & & \multirow{2}{*}{$\begin{array}{c}A A=7 \& H=1 \\
\text { Lost to } \\
\text { follow-up } \mathrm{H}=\end{array}$} & \multirow[t]{2}{*}{$\mathrm{H}=5$} & & \\
\hline $\mathrm{AA}=15$ & $\mathrm{H}=48$ & & & $A A=2$ & $\mathrm{H}=27$ \\
\hline \multicolumn{2}{|c|}{ Baseline $(n=39)$} & \multicolumn{2}{|c|}{ Lost to follow-up } & \multicolumn{2}{|c|}{$\begin{array}{c}\text { Baseline } \\
(n=24)\end{array}$} \\
\hline $\mathrm{AA}=8$ & $\mathrm{H}=31$ & $\mathrm{H}=1$ & $\mathrm{H}=3$ & $A A=2$ & $\mathrm{H}=22$ \\
\hline \multicolumn{2}{|c|}{3 Month $(n=38)$} & & Lost to follow-up & \multicolumn{2}{|c|}{3 Month $(n=21)$} \\
\hline$A A=8$ & $\mathrm{H}=30$ & & $\mathrm{H}=2$ & $A A=2$ & $\mathrm{H}=19$ \\
\hline \multicolumn{2}{|c|}{6 Month $(n=38)$} & & & \multicolumn{2}{|c|}{6 Month $(n=19)$} \\
\hline $\mathrm{AA}=8$ & $\mathrm{H}=30$ & & & $A A=2$ & $\mathrm{H}=17$ \\
\hline
\end{tabular}

Abbreviations: $\mathrm{AA}=$ African Americans; $\mathrm{H}=$ Hispanics. 
Table 1. Assessments Frequency

\begin{tabular}{|l|c|c|c|c|}
\hline Activity & S & B & $\mathbf{3}$ & $\mathbf{6}$ \\
\hline $\begin{array}{l}\text { Blood collection and analysis: serum 25(OH)D, PTH, creatinine, } \\
\text { cystatin C, hs-CRP, FPG and A1c }\end{array}$ & X & & X & X \\
\hline Urine: albumin and creatinine & X & & X & X \\
\hline Anthropometrics: height, weight and BMI & X & & X & X \\
\hline Demographics, FFQ \& blood pressure & X & X & X & X \\
\hline $\begin{array}{l}\text { Sun Exposure: (Skin Color - reflectance colorimetry using the IMS } \\
\text { SmartProbe 400) }\end{array}$ & X & X & X & X \\
\hline $\begin{array}{l}\text { Determine medications for diabetes and hypertension and monitor } \\
\text { medication changes }\end{array}$ & X & X & X & X \\
\hline Study adherence/compliance: pill count and compliance & X & X & X \\
\hline Monitor safety and toxicity & X & X & X \\
\hline Vitamin D (cholecalciferol) supplements distribution & X & X & \\
\hline
\end{tabular}

Abbreviations: $25(\mathrm{OH}) \mathrm{D}=25$-hydroxy vitamin $\mathrm{D}, \mathrm{PTH}=$ parathyroid hormone, hs-CRP= High-sensitivity C-reactive Protein, $\mathrm{A} 1 \mathrm{C}=$ hemoglobin $\mathrm{A} 1 \mathrm{c}, \mathrm{FFQ}=$ food frequency questionnaire, $(\mathrm{S})=$ screening, $(\mathrm{B})=$ baseline.

\section{Safety of the Intervention and Monitoring}

Participants were monitored monthly for any symptoms of vitamin $D_{3}$ toxicity (nausea, vomiting, polyuria, polydipsia, weakness, nervousness, etc.) by telephone, and at each follow-up visit that measured serum 25(OH)D levels. Study adherence and compliance was assessed using serum 25(OH)D and PTH levels change, pill count and attendance of scheduled visits at the clinics. Compliance to the vitamin $\mathrm{D}_{3}$ supplementation was defined as taken more than $80 \%$ of the pills. To facilitate reporting to the clinics at data collection times, a modest compensation for time and travel and laboratory reports were provided. A Data Safety Monitoring Board (DSMB) monitored the safety of vitamin $\mathrm{D}_{3}$ supplementation every 12 month intervals for two years. This included evaluation 
of participant's enrollment, follow-up visits, compliance, laboratory results, and data management.

\section{Vitamin $D_{3}$ Supplements}

Vitamin $\mathrm{D}_{3}$ (cholecalciferol) supplements at 4,000 IU and 6,000 IU were custom manufactured by Biotech Pharmacal, Inc. (Fayetteville, AZ, U.S.) in a single batch for each strength to avoid variation between lots. Since there was a three-year expiration date, participants received the same 4,000 IU or 6,000 IU lots accordingly. A certificate of Analysis was provided by the manufacturer to assure that the product meets research specifications.

\section{Blood Collection}

Fasting venous blood $(20 \mathrm{ml})$ was collected from each participant by a certified phlebotomist using standard laboratory methods. After coagulation, blood was centrifuged at 2500 RPM for 30 minutes. Solstas Lab Partners, Davie, FL, U.S. performed blood and urine analyses using the standard procedures as outlined.

Serum 25(OH)D levels were measured with an enzyme-immunoassay kit by absorbance (Immunodiagnostic Systems; Scottsdale, AZ, U.S.), where the color intensity is proportional to the concentration of $25(\mathrm{OH}) \mathrm{D}$. 
Parathyroid Hormone was tested by a two-sided ELISA (Enzyme-Linked ImmonoSorbent Assay) for the measurement of the biologically active 84 amino acid chain of PTH.

Hemoglobin A1c was measured from whole blood samples using the Roche Tina Quant methods and fasting plasma glucose was measured by hexokinase enzymatic methods by Solstas Lab Partners, Davie, FL, U.S.

Creatinine (Serum) was measured using the Roche enzymatic method (RocheHitachi P-Module instrument with Roche Creatininase Plus assay, Roche Applied Science, IN, U.S.).

Cystatin $\mathbf{C}$ (Serum) was measured in serum using an enzyme-linked immunosorbent assay (ELISA) method (BioVendor LLC, NC, U.S.).

High Sensitivity-CRP (hs-CRP) was analyzed by Immulite (Diagnostic Products Corporation, Los Angeles, CA). The Immulite assay is a 2-site chemiluminescent enzyme immunometric assay with one monoclonal and one polyclonal anti-CRP antibody.

\section{Urine Collection}

Fresh, single-voided, first morning urine samples were collected from each participant to determine the following biomarkers of kidney function. 
Urinary Albumin: Albumin was determined by immunoturbidmetric assay using the Beckman Coulter microalbumin reagent with polyclonal antiserum. Turbidity was measured at $340 \mathrm{~nm}$ and $700 \mathrm{~nm}$ on a spectrophotometer and albumin was quantitatively determined using calibration curves. The immunoturbidometric assay has been established as high sensitivity and high selectivity method for detection of urinary albumin in normal and abnormal ranges for persons with diabetes.

Creatinine (Urine): This procedure is a modification of the Jaffe method in which creatinine reacts with picric acid at alkaline $\mathrm{pH}$ to form a yellow orange complex. Color intensity is measured against a standard curve.

\section{Estimation of Glomerular Filtration Rate (GFR)}

Glomerular Filtration Rate equations were calculated using the online calculator from the National Kidney Foundation http://www.kidney.org/professionals/KDOQl/gfr_calculator). The online calculator takes into consideration both serum creatinine and serum cystatin C concentrations (CKD-EPI creatinine and CKD-EPI creatinine - cystatin C) as well as age, gender, and race. 
Sociodemographic Data were collected with trained, bilingual interviewers (English/ Spanish). Subjects were asked to complete a sociodemographic questionnaire which included questions related to gender, age, education, income, employment status, health insurance, smoking, and medications.

\section{Vitamin D Intake}

A short food frequency questionnaire containing 22 foods and beverages designed to assess vitamin $\mathrm{D}$ and calcium intake was administered. The questionnaire included participants' frequency of consumption of each food and the serving size. Total vitamin $D$ intake was calculated following the original rubric (Blalock et al., 2003).

\section{Anthropometric Measures}

Height and weight were measured using a Seca balance scale with stadiometer (Seca Corp, Columbia, MD, U.S.). Body mass index (BMI) was calculated as weight in $\mathrm{kg} /$ height in $\mathrm{m}^{2}$. Waist circumference to the nearest 0.1 $\mathrm{cm}$ was measured horizontally with a non-stretchable measuring tape placed midway between the $12^{\text {th }}$ rib and iliac crest at minimal respiration to determine central obesity (NHLBI, 1998). Each measurement was taken twice and averaged. 


\section{Sun Exposure - (Skin Color)}

Skin color was determined by reflectance colorimetry using the IMS SmartProbe 400, Milford, CT. The instrument uses the International Commission on Illumination Scale which ranges from 0 (black) to 100 (white) for skin color. Two readings for each participant were taken, one on the right-hand wrist (area most exposed to the sun) and other under the right upper arm (area least exposed to the sun). The differences between the two measures were determined to calculate the delta of skin color due to sun exposure.

\section{$\underline{\text { Statistical Analysis }}$}

All data analyses were conducted on an "intent to treat" basis. Normal distribution of all continuous variables was assessed using Shapiro-Wilk test. Data was reported as means with standard deviation for continuous variables and count and percentages for categorical variables. Independent t-test (parametric) or Mann-Whitney U-test (non-parametric) for continuous variables and chi-square test for categorical variables were used to compare differences in baseline characteristics of participants across the two intervention groups $(4,000$ $\mathrm{IU} / \mathrm{d}$ vs. $6,000 \mathrm{IU} / \mathrm{d}$ ). Paired t-test was used evaluated pre- and post-intervention (time effect) for normally distributed variables and Wilcoxon signed-rank test was used for non-normally distributed variables for each study group.

Results from aims 1 and 2 were reported as mean with standard error. Linear mixed models were performed using, 25(OH)D levels, estimated glomerular 
filtration rate (eGFR) equations, microalbuminuria, systolic and diastolic blood pressure levels as the dependent variables, respectively. The interaction between time and intervention was included to evaluate the dosage effect on the change of the dependent variables over time. Least Significant Difference (LSD) comparisons test were used to detect significant differences within and between 4,000 IU/d and 6,000 IU/d groups from baseline, 3 and 6 months on the outcome variables without and with the adjustment of confounders. Linear mixed models included the adjustment variables that were major confounders of serum 25(OH)D, kidney function and cardiovascular disease. Potential additional covariates were tested by correlation with the dependent variable. Adjustment variables included: age; gender; BMI; duration of diabetes; hemoglobin A1c; vitamin D intake; sun exposure; serum vitamin D; and medication(s) usage. Covariates that were related to outcomes were included as needed. The analyses were conducted using SPSS software (SPSS Inc., Chicago, IL, U.S.) version 23. All tests were analyzed two-sided and a significance level of $<0.05$ was used to decide the statistical significance.

\section{Sample Size and Power Analysis}

A statistical power analysis was performed using PASS 15 (Power Analysis and Sample Size) 2017 Statistical Software (UT, U.S.) for Mixed Models, withinbetween groups interaction. Given an alpha of 0.05 , a sample size of $n=63(n=39$ for the group 4,000 IU/d and $n=24$ for the $6,000 \mathrm{IU} / \mathrm{d}$ ) will have $82.0 \%$ power to detect difference in eGFR (CKD-EPI) creatinine from baseline to 6 months. Thus, 
the sample size of $n=63$ was more than adequate for the main outcome of this study and allowed to adjust for possible confounding factors. Additionally, power analyses were calculated for other outcomes in the study (Table 2).

Table 2. Outcomes Power Calculation

\begin{tabular}{|l|c|c|c|}
\hline \multicolumn{1}{|c|}{ Outcomes } & Power & Sample & Alpha \\
\hline 25-hydroxy vitamin D & & 57 & 0.05 \\
\hline eGFR (CKD-EPI creatinine) & $82.0 \%$ & 57 & 0.05 \\
\hline eGFR (CKD-EPI creatinine - cystatin C) & $84.0 \%$ & 57 & 0.05 \\
\hline Microalbuminuria & $70.0 \%$ & 57 & 0.05 \\
\hline Systolic Blood Pressure & $84.0 \%$ & 57 & 0.05 \\
\hline Diastolic Blood Pressure & $79.0 \%$ & 57 & 0.05 \\
\hline
\end{tabular}

Abbreviations: eGFR= Estimated Glomerular Filtration Rate; CKD-EPI=Chronic Kidney Disease Epidemiology. 


\section{CHAPTER III: RESULTS}

\section{Baseline Comparisons of Vitamin $\mathrm{D}_{3}$ Intervention Groups}

The participants in this study were $53.4 \pm 8.3$ years old $(4,000 \mathrm{IU} / \mathrm{d}$ group) and $55.0 \pm 10.3$ years old $(6,000 \mathrm{IU} / \mathrm{d}$ group), the majority were female in both groups $71.8 \%$ (4,000 IU/d group) and 58.3\% (6,000 IU/d group) respectively. The mean known duration of diabetes was $6.1 \pm 4.7$ years in the $4,000 \mathrm{IU} / \mathrm{d}$ group and $6.8 \pm 6.4$ years in the group receiving $6,000 \mathrm{IU} / \mathrm{d}$, and $\mathrm{BMI}$ above $30 \mathrm{~kg} / \mathrm{m}^{2}$ in both intervention groups classified them in the obesity category. All participants started the study with serum $25(\mathrm{OH}) \mathrm{D}$ levels considered as deficient/insufficient $(20.7 \pm 6.0 \mathrm{ng} / \mathrm{mL}$ in the $4,000 \mathrm{IU} / \mathrm{d}$ group and $21.7 \pm 5.6 \mathrm{ng} / \mathrm{mL}$ in the $6,000 \mathrm{IU} / \mathrm{d}$ group). At baseline, participants at the 4,000 IU/d group had significantly lower systolic blood pressure levels $(126.9 \pm 18.2 \mathrm{mmHg})$ and diastolic blood pressure levels $(82.3 \pm 10.7 \mathrm{mmHg}$ ) as compared with those in the $6,000 \mathrm{IU} / \mathrm{d}$ group [(146.2 $\pm 22.1 \mathrm{mmHg}, p<.001)$ and $(91.9 \pm 10.9 \mathrm{mmHg}, p=0.001)$ respectively]. The $4,000 \mathrm{IU} / \mathrm{d}$ group had lower percentage of smokers $(7.7 \%$ vs. $25.0 \%, p=0.057)$ and higher serum creatinine levels $(0.92 \pm 0.24 \mathrm{mg} / \mathrm{dL}$ vs. $0.80 \pm 0.20 \mathrm{mg} / \mathrm{dL}$, $\mathrm{p}=0.066$ ) as compare with the $6,000 \mathrm{IU} / \mathrm{d}$ group. Participants in the $4,000 \mathrm{IU} / \mathrm{d}$ group had significantly lower CKD-EPI creatinine values $(84.6 \pm 18.4 \mathrm{~mL} / \mathrm{min})$ compared with those in the $6,000 \mathrm{IU} / \mathrm{d}$ group $(94.2 \pm 17.5 \mathrm{~mL} / \mathrm{min}, \mathrm{p}=0.027)$ (Table 1). 
Table 1. Baseline Comparisons of Vitamin $D_{3}$ Intervention Groups

\begin{tabular}{|c|c|c|c|}
\hline \multirow{2}{*}{ Variables } & \multicolumn{2}{|c|}{ Intervention } & \multirow[b]{2}{*}{$P$-Value } \\
\hline & $\begin{array}{c}4,000 \mathrm{lU} / \mathrm{d} \\
\mathrm{n}=39\end{array}$ & $\begin{array}{c}6,000 \mathrm{lU} / \mathrm{d} \\
\mathrm{n}=24\end{array}$ & \\
\hline Age (years) & $53.4 \pm 8.3$ & $55.0 \pm 10.3$ & 0.499 \\
\hline Sex (Female) $n(\%)$ & $28(71.8)$ & 14(58.3) & 0.271 \\
\hline BMI $\left(\mathrm{kg} / \mathrm{m}^{2}\right)$ & $34.7 \pm 7.6$ & $32.7 \pm 6.0$ & 0.492 \\
\hline Waist circumference $(\mathrm{cm})$ & $109.6 \pm 18.6$ & $107.3 \pm 12.4$ & 0.388 \\
\hline Known years with diabetes & $6.1 \pm 4.7$ & $6.8 \pm 6.4$ & 0.983 \\
\hline Smoking (yes) $n(\%)$ & $3(7.7)$ & $6(25.0)$ & 0.057 \\
\hline Marital Status (married, yes) $n(\%)$ & $22(56.4)$ & $11(45.8)$ & 0.862 \\
\hline Employment (yes) $n(\%)$ & $22(56.4)$ & $15(62.5)$ & 0.383 \\
\hline Medical insurance (yes) $n(\%)$ & 19(48.7) & $11(45.8)$ & 0.824 \\
\hline Diabetes medications (yes) $n(\%)$ & $36(92.3)$ & $22(91.7)$ & 0.927 \\
\hline Blood pressure medications (yes) $n(\%)$ & $26(66.7)$ & 14(58.3) & 0.505 \\
\hline Systolic blood pressure (mmHg) & $126.9 \pm 18.2$ & $146.2 \pm 22.1$ & $<0.001$ \\
\hline Diastolic blood pressure $(\mathrm{mmHg})$ & $82.3 \pm 10.7$ & $91.9 \pm 10.9$ & 0.001 \\
\hline \multicolumn{4}{|l|}{ Blood Biomarkers } \\
\hline $25(\mathrm{OH}) \mathrm{D}(\mathrm{ng} / \mathrm{mL})$ & $20.7 \pm 6.0$ & $21.7 \pm 5.6$ & 0.457 \\
\hline PTH (pmol/L) & $39.4 \pm 19.5$ & $42.6 \pm 16.5$ & 0.322 \\
\hline Insulin $(\mu \mathrm{U} / \mathrm{mL})$ & $14.1 \pm 14.1$ & $11.5 \pm 7.2$ & 0.697 \\
\hline $\mathrm{FGP}(\mathrm{mg} / \mathrm{dL})$ & $189.0 \pm 88.7$ & $184.4 \pm 71.6$ & 0.944 \\
\hline $\mathrm{A} 1 \mathrm{c}(\%)$ & $8.4 \pm 2.3$ & $8.8 \pm 2.2$ & 0.282 \\
\hline Hs-CRP (mg/L) & $9.7 \pm 13.4$ & $5.7 \pm 4.0$ & 0.860 \\
\hline Cystatin $\mathrm{C}(\mathrm{mg} / \mathrm{L})$ & $0.70 \pm 0.19$ & $0.70 \pm 0.25$ & 0.865 \\
\hline Serum creatinine $(\mathrm{mg} / \mathrm{dL})$ & $0.92 \pm 0.24$ & $0.80 \pm 0.20$ & 0.066 \\
\hline \multicolumn{4}{|l|}{ Urinary Biomarkers } \\
\hline Creatinine (mg/dL) & $127.6 \pm 57.8$ & $131.9 \pm 65.0$ & 0.777 \\
\hline MAU (mg/dL) & $4.5 \pm 15.2$ & $6.9 \pm 15.1$ & 0.152 \\
\hline \multicolumn{4}{|l|}{ Estimated GFR Equations } \\
\hline CKD-EPI creatinine (mL/min) & $84.6 \pm 18.4$ & $94.2 \pm 17.5$ & 0.027 \\
\hline $\begin{array}{l}\text { CKD-EPI creatinine - cystatin C } \\
(\mathrm{mL} / \mathrm{min})\end{array}$ & $112.6 \pm 21.5$ & $114.0 \pm 23.2$ & 0.112 \\
\hline \multicolumn{4}{|l|}{ Sun exposure } \\
\hline Upper arm skin color & $58.9 \pm 9.8$ & $60.4 \pm 7.3$ & 0.837 \\
\hline Forearm skin color & $55.2 \pm 8.7$ & $56.6 \pm 6.0$ & 0.915 \\
\hline Delta of skin color & $3.7 \pm 3.6$ & $3.9 \pm 5.0$ & 0.510 \\
\hline \multicolumn{4}{|l|}{ Dietary } \\
\hline Vitamin D intake (IU/d) & $127.0 \pm 82.7$ & $122.2 \pm 86.4$ & 0.692 \\
\hline Multivitamins (yes) $n(\%)$ & $9(23.1)$ & $5(20.8)$ & 0.835 \\
\hline Alcohol intake $n(\%)$ & & & 0.781 \\
\hline None & $28(71.8)$ & $18(75.0)$ & \\
\hline 1 or more servings per week & $11(28.2)$ & $6(25.0)$ & \\
\hline
\end{tabular}

Abbreviations: $\mathrm{BMl}=$ body mass index; $25(\mathrm{OH}) \mathrm{D}=25$-hydroxy vitamin $\mathrm{D}$;

$\mathrm{PTH}=$ parathyroid hormone; $\mathrm{A} 1 \mathrm{c}=$ glycated hemoglobin; $\mathrm{FPG}=$ fasting plasma glucose; 
$\mathrm{MAU}=$ microalbuminuria; GFR= Glomerular filtration rate; CKD-EPI=Chronic Kidney

Disease Epidemiology Collaboration; $d=d a y ; S D=$ standard deviation. Data reported as Mean $\pm S D$; unless otherwise indicated. $P$ is considered significant at $<0.05$.

\section{Paired Comparisons of Vitamin $D_{3}$ at 4,000 IU from Pre- to Post-}

\section{Intervention}

Findings from paired comparisons of vitamin $\mathrm{D}_{3}$ at $4,000 \mathrm{lU} / \mathrm{d}$ from pre- to postinterventions are shown in Table 2. Serum 25(OH)D levels significantly increased from baseline $(20.7 \pm 6.0 \mathrm{ng} / \mathrm{mL})$ to 6 months $(37.9 \pm 13.2 \mathrm{ng} / \mathrm{mL}$, $\mathrm{p}<0.001)$. Cystatin $\mathrm{C}$ levels were significantly different from baseline $(0.70 \pm 0.19$ $\mathrm{mg} / \mathrm{L})$ to 6 months $(0.79 \pm 0.28 \mathrm{mg} / \mathrm{L}, \mathrm{p}=0.045)$. Serum creatinine levels significantly decreased from baseline $(0.92 \pm 0.24 \mathrm{mg} / \mathrm{dL})$ to 6 months $(0.83 \pm 0.25$ $\mathrm{mg} / \mathrm{dL}, \mathrm{p}=0.001)$. CKD-EPI creatinine values significantly increased from baseline $(84.6 \pm 18.4 \mathrm{~mL} / \mathrm{min})$ to 6 months $(92.4 \pm 18.9 \mathrm{~mL} / \mathrm{min}, \mathrm{p}<0.001)$. On the other hand, CKD-EPI creatinine - cystatin $C$ values significantly decreased from baseline $(112.6 \pm 21.5 \mathrm{~mL} / \mathrm{min})$ to 6 months $(98.6 \pm 24.0 \mathrm{~mL} / \mathrm{min}, \mathrm{p}=0.022)$ (Table 2). 
Table 2. Paired Comparisons of Vitamin $D_{3}$ at 4,000 IU from Pre- to PostIntervention

\begin{tabular}{|c|c|c|c|}
\hline \multirow[b]{2}{*}{ Variables } & \multicolumn{2}{|c|}{$\begin{array}{c}\text { Intervention }(4,000 \mathrm{lU} / \mathrm{d}) \\
\mathrm{n}=39\end{array}$} & \multirow[b]{2}{*}{$P$-Value } \\
\hline & Baseline & 6 months & \\
\hline $\mathrm{BMI}\left(\mathrm{kg} / \mathrm{m}^{2}\right)$ & $34.7 \pm 7.6$ & $35.4 \pm 7.5$ & 0.136 \\
\hline Waist circumference $(\mathrm{cm})$ & $109.6 \pm 18.6$ & $109.0 \pm 17.8$ & 0.913 \\
\hline Systolic blood pressure $(\mathrm{mmHg})$ & $126.9 \pm 18.2$ & $127.9 \pm 17.0$ & 0.690 \\
\hline Diastolic blood pressure (mmHg) & $82.3 \pm 10.7$ & $83.5 \pm 9.1$ & 0.459 \\
\hline \multicolumn{4}{|l|}{ Blood biomarkers } \\
\hline $25(\mathrm{OH}) \mathrm{D}(\mathrm{ng} / \mathrm{mL})$ & $20.7 \pm 6.0$ & $37.9 \pm 13.2$ & $<0.001$ \\
\hline PTH (pmol/L) & $39.4 \pm 19.5$ & $37.2 \pm 17.8$ & 0.149 \\
\hline Insulin $(\mu \mathrm{U} / \mathrm{mL})$ & $14.1 \pm 14.1$ & $11.4 \pm 8.1$ & 0.267 \\
\hline $\mathrm{FGP}(\mathrm{mg} / \mathrm{dl})$ & $189.0 \pm 88.7$ & $170.1 \pm 73.6$ & 0.133 \\
\hline$A 1 c(\%)$ & $8.4 \pm 2.3$ & $8.2 \pm 2.1$ & 0.787 \\
\hline Hs-CRP (mg/L) & $9.7 \pm 13.4$ & $7.4 \pm 7.0$ & 0.602 \\
\hline Cystatin C (mg/L) & $0.70 \pm 0.19$ & $0.79 \pm 0.28$ & 0.045 \\
\hline Serum creatinine (mg/dL) & $0.92 \pm 0.24$ & $0.83 \pm 0.25$ & 0.001 \\
\hline \multicolumn{4}{|l|}{ Urinary biomarkers } \\
\hline Creatinine (mg/dL) & $127.6 \pm 57.8$ & $143.3 \pm 67.8$ & 0.500 \\
\hline MAU $(\mathrm{mg} / \mathrm{dL})$ & $4.5 \pm 15.2$ & $3.4 \pm 9.0$ & 0.816 \\
\hline \multicolumn{4}{|l|}{ Estimated GFR Equations } \\
\hline CKD-EPI creatinine $(\mathrm{mL} / \mathrm{min})$ & $84.6 \pm 18.4$ & $92.4 \pm 18.9$ & $<0.001$ \\
\hline $\begin{array}{l}\text { CKD-EPI creatinine - cystatin C } \\
(\mathrm{mL} / \mathrm{min})\end{array}$ & $112.6 \pm 21.5$ & $98.6 \pm 24.0$ & 0.022 \\
\hline \multicolumn{4}{|l|}{ Sun exposure } \\
\hline Upper arm skin color & $58.9 \pm 9.8$ & $59.3 \pm 9.9$ & 0.346 \\
\hline Forearm skin color & $55.2 \pm 8.7$ & $55.5 \pm 8.6$ & 0.827 \\
\hline Delta of skin color & $3.7 \pm 3.6$ & $3.8 \pm 4.2$ & 0.971 \\
\hline \multicolumn{4}{|l|}{ Dietary } \\
\hline Vitamin D intake (IU/d) & $127.0 \pm 82.7$ & $132.8 \pm 90.4$ & 0.913 \\
\hline
\end{tabular}

Abbreviations: $\mathrm{BMI}=$ body mass index; $25(\mathrm{OH}) \mathrm{D}=25$-hydroxy vitamin $\mathrm{D}$;

$\mathrm{PTH}=$ parathyroid hormone; $\mathrm{A} 1 \mathrm{c}=$ glycated hemoglobin; $\mathrm{FPG}=$ fasting plasma glucose; $\mathrm{MAU}=$ microalbuminuria; GFR= Glomerular filtration rate; CKD-EPI=Chronic Kidney Disease Epidemiology Collaboration; $d=d a y ; S D=$ standard deviation. Data reported as Mean $\pm S D$; unless otherwise indicated. $P$ is considered significant at $<0.05$. 
Table 3 shows findings from paired comparisons of vitamin $D_{3}$ at $6,000 \mathrm{IU} / \mathrm{d}$ from pre- to post- intervention. Systolic blood pressure levels $(146.2 \pm 22.1$ $\mathrm{mmHg})$ significantly decreased from baseline to 6 months $(135.0 \pm 17.8 \mathrm{mmHg}$, $\mathrm{p}=0.009)$ and diastolic blood pressure marginally decreased $(91.9 \pm 10.9 \mathrm{mmHg}$ to $87.9 \pm 10.7 \mathrm{mmHg}, \mathrm{p}=0.077)$. Serum $25(\mathrm{OH}) \mathrm{D}$ levels significantly increased from baseline $(21.7 \pm 5.6 \mathrm{ng} / \mathrm{mL})$ to 6 months $(38.9 \pm 16.3 \mathrm{ng} / \mathrm{mL}, p<0.001)$. Serum creatinine levels significantly decreased from baseline $(0.80 \pm 0.20 \mathrm{mg} / \mathrm{dL})$ to 6 months $(0.74 \pm 0.20 \mathrm{mg} / \mathrm{dL}, \mathrm{p}=0.004)$. CKD-EPI creatinine values significantly increased from baseline $(94.2 \pm 17.5 \mathrm{~mL} / \mathrm{min})$ to 6 months $(97.9 \pm 18.0 \mathrm{~mL} / \mathrm{min}$, $p=0.047)$. There were marginally significant differences from baseline $(56.6 \pm 6.0)$ to 6 months $(57.0 \pm 6.6, p=0.077)$ in forearm sun exposure scores. 
Table 3. Paired Comparisons of Vitamin $D_{3}$ at 6,000 IU from Pre- to PostIntervention

\begin{tabular}{|c|c|c|c|}
\hline \multirow{2}{*}{ Variables } & \multicolumn{2}{|c|}{$\begin{array}{c}\text { Intervention }(6,000 \mathrm{lU} / \mathrm{d}) \\
\mathrm{n}=24\end{array}$} & \multirow{2}{*}{$\begin{array}{c}P- \\
\text { Value }\end{array}$} \\
\hline & Baseline & 6 months & \\
\hline $\mathrm{BMI}\left(\mathrm{kg} / \mathrm{m}^{2}\right)$ & $32.7 \pm 6.0$ & $33.1 \pm 6.3$ & 0.970 \\
\hline Waist circumference (cm) & $107.3 \pm 12.4$ & $102.7 \pm 24.9$ & 0.404 \\
\hline Systolic blood pressure $(\mathrm{mmHg})$ & $146.2 \pm 22.1$ & $135.0 \pm 17.8$ & 0.009 \\
\hline Diastolic blood pressure (mmHg) & $91.9 \pm 10.9$ & $87.9 \pm 10.7$ & 0.077 \\
\hline \multicolumn{4}{|l|}{ Blood biomarkers } \\
\hline $25(\mathrm{OH}) \mathrm{D}(\mathrm{ng} / \mathrm{mL})$ & $21.7 \pm 5.6$ & $38.9 \pm 16.3$ & $<0.001$ \\
\hline PTH (pmol/L) & $42.6 \pm 16.5$ & $38.3 \pm 17.3$ & 0.052 \\
\hline Insulin $(\mu \mathrm{U} / \mathrm{mL})$ & $11.5 \pm 7.2$ & $11.4 \pm 7.1$ & 0.577 \\
\hline $\mathrm{FGP}(\mathrm{mg} / \mathrm{dl})$ & $184.4 \pm 71.6$ & $180.7 \pm 73.9$ & 0.697 \\
\hline $\mathrm{A} 1 \mathrm{c}(\%)$ & $8.8 \pm 2.2$ & $8.6 \pm 2.0$ & 0.139 \\
\hline $\mathrm{Hs}-\mathrm{CRP}(\mathrm{mg} / \mathrm{L})$ & $5.7 \pm 4.0$ & $7.4 \pm 7.1$ & 0.270 \\
\hline Cystatin C (mg/L) & $0.70 \pm 0.25$ & $0.75 \pm 1.9$ & 0.365 \\
\hline Serum creatinine $(\mathrm{mg} / \mathrm{dL})$ & $0.80 \pm 0.20$ & $0.74 \pm 0.20$ & 0.004 \\
\hline \multicolumn{4}{|l|}{ Urinary biomarkers } \\
\hline Creatinine (mg/dL) & $131.9 \pm 65.0$ & $117.1 \pm 48.4$ & 0.306 \\
\hline $\mathrm{MAU}(\mathrm{mg} / \mathrm{dL})$ & $6.9 \pm 15.1$ & $7.0 \pm 14.2$ & 0.370 \\
\hline \multicolumn{4}{|l|}{ Estimated GFR Equations } \\
\hline CKD-EPI creatinine (mL/min) & $94.2 \pm 17.5$ & $97.9 \pm 18.0$ & 0.047 \\
\hline $\begin{array}{l}\text { CKD-EPI creatinine - cystatin C } \\
(\mathrm{mL} / \mathrm{min})\end{array}$ & $114.0 \pm 23.2$ & $107.4 \pm 20.1$ & 0.270 \\
\hline \multicolumn{4}{|l|}{ Sun exposure } \\
\hline Upper arm skin color & $60.4 \pm 7.3$ & $61.1 \pm 6.5$ & 0.173 \\
\hline Forearm skin color & $56.6 \pm 6.0$ & $57.0 \pm 6.6$ & 0.072 \\
\hline Delta of skin color & $3.9 \pm 5.0$ & $4.2 \pm 4.6$ & 0.417 \\
\hline \multicolumn{4}{|l|}{ Dietary } \\
\hline Vitamin D intake (IU/d) & $122.2 \pm 86.4$ & $115.9 \pm 82.9$ & 0.638 \\
\hline
\end{tabular}

Abbreviations: $\mathrm{BMI}=$ body mass index; $25(\mathrm{OH}) \mathrm{D}=25$-hydroxy vitamin $\mathrm{D}$;

$\mathrm{PTH}=$ parathyroid hormone; $\mathrm{A} 1 \mathrm{c}=$ glycated hemoglobin; $\mathrm{FPG}=$ fasting plasma glucose; $\mathrm{MAU}=$ microalbuminuria; GFR= Glomerular filtration rate; CKD-EPI=Chronic Kidney Disease Epidemiology Collaboration; $\mathrm{d}=\mathrm{day} ; \mathrm{SD}=$ standard deviation. Data reported as Mean $\pm S D$; unless otherwise indicated. $P$ is considered significant at $<0.05$. 
Aim 1: To evaluate the effect of vitamin $\mathrm{D}_{3}$ supplementation (cholecalciferol) at 6,000 IU/d vs. 4,000 IU/d on kidney function among Hispanics and African Americans with type 2 diabetes and hypovitaminosis $D(<30 \mathrm{ng} / \mathrm{ml})$.

Hypothesis 1: Vitamin $D_{3}$ supplementation at $6,000 \mathrm{lU} / \mathrm{d}$ will be more effective in raising $25(\mathrm{OH}) \mathrm{D}$ levels from deficient/insufficient to sufficient as compared to $4,000 \mathrm{IU} / \mathrm{d}$ over 6 months.

Unadjusted linear mixed models indicated statistically significant effect of time on serum $25(\mathrm{OH}) \mathrm{D}$ levels $(\mathrm{p}<0.001)$. However, the effect of intervention $(p=0.294)$ and interaction between time and intervention $(p=0.120)$ were not statistically significant. Post-hoc LSD analyses showed significant improvements in serum $25(\mathrm{OH}) \mathrm{D}$ levels over time in both intervention groups. In the 4,000 IU/d and 6,000 IU/d groups respectively, significant increase in serum 25(OH)D levels were observed from baseline $[(20.7 \pm 0.9 \mathrm{ng} / \mathrm{mL})$ and $(21.7 \pm 1.2 \mathrm{ng} / \mathrm{mL})]$ to 3 months $[(37.0 \pm 2.1 \mathrm{ng} / \mathrm{mL}, \mathrm{p}<0.001)$ and $(42.6 \pm 2.6 \mathrm{ng} / \mathrm{mL}, \mathrm{p}<0.001)]$ and to 6 months $[(37.9 \pm 2.3 \mathrm{ng} / \mathrm{mL}, \mathrm{p}<0.001)$ and $(38.9 \pm 2.9 \mathrm{ng} / \mathrm{mL}, \mathrm{p}<0.001)]$ respectively (Table 4). 
Table 4. Unadjusted and Adjusted Intervention Groups Comparisons of 25(OH)D at Different Time Points

\begin{tabular}{|c|c|c|}
\hline \multirow[b]{2}{*}{ Unadjusted } & \multicolumn{2}{|c|}{ Intervention } \\
\hline & $\begin{array}{c}4,000 \mathrm{IU} / \mathrm{d} \\
n=39\end{array}$ & $\begin{array}{c}6,000 \mathrm{IU} / \mathrm{d} \\
n=24\end{array}$ \\
\hline 25(OH)D (ng/mL) & \multicolumn{2}{|c|}{ Mean \pm SE } \\
\hline Baseline & $20.7 \pm 0.9$ & $21.7 \pm 1.2$ \\
\hline 3 months & $37.0 \pm 2.1^{*}$ & $42.6 \pm 2.6^{*}$ \\
\hline 6 months & $37.9 \pm 2.3^{*}$ & $38.9 \pm 2.9^{*}$ \\
\hline$P$-value time $=0.001$ & $P$-value intervention $=0.294$ & $P$-value interaction $=0.120$ \\
\hline \multicolumn{3}{|l|}{ Adjusted } \\
\hline 25(OH)D (ng/mL) & \multicolumn{2}{|c|}{ Mean $\pm S E$} \\
\hline Baseline & $19.8 \pm 1.1$ & $21.4 \pm 1.2$ \\
\hline 3 months & $36.1 \pm 2.2^{*}$ & $43.0 \pm 2.7^{* ; * *}$ \\
\hline 6 months & $37.1 \pm 2.4^{*}$ & $39.2 \pm 3.0^{*}$ \\
\hline$P$-value time $=0.001$ & $P$-value intervention $=0.143$ & $P$-value interaction $=0.088$ \\
\hline
\end{tabular}

Abbreviations: $\mathrm{BMl}=$ body mass index; $25(\mathrm{OH}) \mathrm{D}=25$-hydroxy vitamin $\mathrm{D} ; \mathrm{A} 1 \mathrm{c}=$ glycated hemoglobin; SE=standard error. ${ }^{*}$ Represents significant differences from baseline; ** represents significant differences from 3 to 6 months.

Adjustment variables: age gender, BMI, known years with diabetes, A1c, diabetes medications, blood pressure medications, 25(OH)D, vitamin D intake, sun exposure. Data reported as Mean \pm SE. $P$ is considered significant at $<0.05$. 
Adjusted linear mixed models after including covariates in the analysis, a statistically significant effect of time on $25(\mathrm{OH})$ D levels $(p<0.001)$ was observed. However, the effect of intervention between groups was not statistically significant $(p<0.143)$. There was a marginally significant result for the interaction between time and intervention ( $p=0.088$ ). In the $4,000 \mathrm{IU} / \mathrm{d}$ and $6,000 \mathrm{IU} / \mathrm{d}$ groups, a significant increase in serum $25(\mathrm{OH}) \mathrm{D}$ levels were observed from baseline $[(19.9 \pm 1.1 \mathrm{ng} / \mathrm{mL})$ and $(21.4 \pm 1.3 \mathrm{ng} / \mathrm{mL})]$ to 3 months $[(36.1 \pm 2.2 \mathrm{ng} / \mathrm{mL}$, $\mathrm{p}<.001)$ and $(43.0 \pm 2.7 \mathrm{ng} / \mathrm{mL}, \mathrm{p}<0.001)]$ and 6 months $[(37.1 \pm 2.4 \mathrm{ng} / \mathrm{mL}$, $\mathrm{p}<0.001)$ and $(39.2 \pm 3.0 \mathrm{ng} / \mathrm{mL}, \mathrm{p}<0.001)]$, respectively. Moreover, in the 6,000 IU group, there was a significant decrease in serum 25(OH)D levels from 3 months (43.0 $\pm 2.7 \mathrm{ng} / \mathrm{mL})$ to 6 months $(39.2 \pm 3.0 \mathrm{ng} / \mathrm{mL}, \mathrm{p}=0.046)$ (Table 4).

Hypothesis 2: Vitamin $D_{3}$ supplementation at 6,000 IU/d will be more effective in increasing eGFR using CKD-EPI creatinine when compared to 4,000 IU/d over 6 months.

Unadjusted linear mixed models showed that the effect of time on CKD-EPI creatinine was statistically significant $(p<0.001)$, intervention effect was marginally significant $(p=0.067)$; however, the interaction between time and intervention was not statistically significant $(p=0.110)$. Post-hoc LSD analyses showed that there was a marginally significant increase in CKD-EPI creatinine values from baseline $(84.6 \pm 2.8 \mathrm{~mL} / \mathrm{min})$ to 3 months $(88.0 \pm 2.9 \mathrm{~mL} / \mathrm{min}, \mathrm{p}=0.077)$ and significant increase in CKD-EPI creatinine values to 6 months (92.5 \pm 2.9 
$\mathrm{mL} / \mathrm{min}, \mathrm{p}<0.001$ ) in the $4,000 \mathrm{IU} / \mathrm{d}$ group. Moreover, significant increase was found from 3 months to 6 months ( $p=0.004$ ) in the 4,000 IU/d group. In the 6,000 IU/d group, marginally significant increase in mean CKD-EPI creatinine were observed from baseline $(94.2 \pm 3.6 \mathrm{~mL} / \mathrm{min})$ to 6 months $(97.9 \pm 3.7 \mathrm{~mL} / \mathrm{min}$, $\mathrm{p}=0.082)$.

Adjusted linear mixed models indicated that the effect of time $(p<0.001)$ on CKD-EPI creatinine was statistically significant. However, the intervention effect $(p=0.0162)$ and the interaction effect of time and intervention were not statistically significant $(p=0.121)$. Post-hoc analysis showed marginally significant increase in CKD-EPI creatinine values from baseline $(83.8 \pm 3.2 \mathrm{~mL} / \mathrm{min})$ to 3 months $(88.0 \pm 3.0 \mathrm{~mL} / \mathrm{min}, \mathrm{p}=0.074)$ and statistically significant increase to 6 months $(93.0 \pm 3.1 \mathrm{~mL} / \mathrm{min}, \mathrm{p}<0.001)$ in the $4,000 \mathrm{IU} / \mathrm{d}$ group. Moreover, significant improvements in CKD-EPI creatinine values were also observed from 3 months $(88.0 \pm 3.0 \mathrm{~mL} / \mathrm{min})$ to 6 months $(93.0 \pm 3.1 \mathrm{~mL} / \mathrm{min}, \mathrm{p}=0.002)$ in the $4,000 \mathrm{IU} / \mathrm{d}$ group. Marginally significant increase in mean CKD-EPI creatinine values from baseline $(90.1 \pm 3.9 \mathrm{~mL} / \mathrm{min})$ to 6 months $(96.0 \pm 3.9 \mathrm{~mL} / \mathrm{min}, \mathrm{p}=0.059)$ were found in the 6,000 IU/d group (Table 5). 
Table 5. Unadjusted and Adjusted Intervention Groups Comparisons of CKD-EPI creatinine at Different Time Points

\begin{tabular}{|c|c|c|}
\hline \multirow[b]{2}{*}{ Unadjusted } & \multicolumn{2}{|c|}{ Intervention } \\
\hline & $\begin{array}{c}4,000 \mathrm{IU} / \mathrm{d} \\
n=39\end{array}$ & $\begin{array}{c}6,000 \mathrm{IU} / \mathrm{d} \\
n=24\end{array}$ \\
\hline CKD-EPI creatinine (mL/min) & \multicolumn{2}{|c|}{ Mean士SE } \\
\hline Baseline & $84.6 \pm 2.8$ & $94.2 \pm 3.6$ \\
\hline 3 months & $88.0 \pm 2.9 * ; * \star$ & $97.7 \pm 3.7$ \\
\hline 6 months & $92.5 \pm 2.9^{*}$ & $97.9 \pm 3.7$ \\
\hline$P$-value time $<0.001$ & $P$-value intervention $=0.067$ & $P$-value interaction $=0.110$ \\
\hline \multicolumn{3}{|l|}{ Adjusted } \\
\hline CKD-EPI creatinine (mL/min) & \multicolumn{2}{|c|}{ Mean \pm SE } \\
\hline Baseline & $83.8 \pm 3.2$ & $91.0 \pm 3.9$ \\
\hline 3 months & $88.0 \pm 3.0 * ; * *$ & $96.0 \pm 3.8$ \\
\hline 6 months & $93.0 \pm 3.2^{*}$ & $96.0 \pm 3.9$ \\
\hline$P$-value time $<0.001$ & $P$-value intervention $=0.162$ & $P$-value interaction $=0.095$ \\
\hline $\begin{array}{l}\text { Abbreviations: } \mathrm{BMI}=\text { body mass } \\
\text { Kidney Disease Epidemiology Coll } \\
\star \star \text { represents significant differences } \\
\text { Adjustment variables: BMI, know } \\
\text { vitamin D intake, sun exposure. De }\end{array}$ & $\begin{array}{l}\text { 25-hydroxy vitamin } D ; A 1 c=g l y c \\
\text { andard error. * Represents sign } \\
\text { ths. } \\
\text { betes, } A 1 c \text {, diabetes medication } \\
\text { lean } \pm S E . P \text { is considered signif }\end{array}$ & $\begin{array}{l}\text { ifferences from baseline; } \\
\text { ipressure medications, } 25(\mathrm{OH}) \mathrm{D} \text {, } \\
<0.05 \text {. }\end{array}$ \\
\hline
\end{tabular}


Hypothesis 3: Vitamin $\mathrm{D}_{3}$ supplementation at $6,000 \mathrm{IU} / \mathrm{d}$ will be more effective in increasing eGFR using CKD-EPI creatinine - cystatin C when compared to 4,000 IU/d over 6 months.

Unadjusted linear mixed models showed that the effect of time on CKD-EPI creatinine - cystatin $\mathbf{C}$ was statistically significant $(p<0.011)$. However, the effect of intervention $(p=0.105)$ or the interaction between time and intervention $(p=0.636)$ were not statistically significant. LSD post-hoc analyses showed a significant decrease in CKD-EPI creatinine - cystatin $C$ values from baseline $(104.9 \pm 3.4 \mathrm{~mL} / \mathrm{min})$ to 6 months $(97.6 \pm 3.2 \mathrm{~mL} / \mathrm{min}, \mathrm{p}=0.029)$ and from 3 months $(106.7 \pm 3.5 \mathrm{~mL} / \mathrm{min})$ to 6 months $(97.6 \pm 3.2 \mathrm{~mL} / \mathrm{min}, \mathrm{p}=0.002)$ in the $4,000 \mathrm{IU} / \mathrm{d}$ group. Additionally, changes in CKD-EPI creatinine - cystatin C values between intervention groups $(4,000 \mathrm{lU} / \mathrm{d}$ vs. $6,000 \mathrm{IU} / \mathrm{d})$ at 6 months were observed at the marginal significance level $(97.6 \pm 3.2 \mathrm{~mL} / \mathrm{min}$ vs. $107.4 \pm 4.1 \mathrm{~mL} / \mathrm{min}, \mathrm{p}=0.066)$ (Table 6).

Adjusted linear mixed models indicated that the effect of time on CKD-EPI creatinine - cystatin $\mathbf{C}$ values were statistically significant $(p=0.020)$. However, the effect of intervention $(p=0.289)$ and time and intervention interaction $(p=0.740)$ were not statistically significant. LSD post-hoc analyses showed a significant decrease in CKD-EPI creatinine - cystatin C values from 3 months $(109.2 \pm 3.9 \mathrm{~mL} / \mathrm{min})$ to 6 months $(100.9 \pm 3.7 \mathrm{~mL} / \mathrm{min}, \mathrm{p}=0.006)$ in the $4,000 \mathrm{IU} / \mathrm{d}$ group. 
Table 6. Unadjusted and Adjusted Intervention Groups Comparisons of CKD-EPI creatinine - cystatin C at Different Time Points

\begin{tabular}{|c|c|c|}
\hline \multirow[b]{2}{*}{ Unadjusted } & \multicolumn{2}{|c|}{ Intervention } \\
\hline & $\begin{array}{c}4,000 \mathrm{IU} / \mathrm{d} \\
\mathrm{n}=39\end{array}$ & $\begin{array}{c}6,000 \mathrm{IU} / \mathrm{d} \\
\mathrm{n}=24\end{array}$ \\
\hline $\begin{array}{l}\text { CKD-EPI creatinine - cystatin C } \\
\text { (mL/min) }\end{array}$ & \multicolumn{2}{|c|}{ Mean \pm SE } \\
\hline Baseline & $104.9 \pm 3.4$ & $112.6 \pm 4.3$ \\
\hline 3 months & $106.7 \pm 3.5^{\star \star}$ & $112.2 \pm 4.5$ \\
\hline 6 months & $97.6 \pm 3.2^{*}$ & $107.4 \pm 4.1$ \\
\hline$P$-value time $=0.011$ & $P$-value intervention $=0.105$ & $P$-value interaction $=0.636$ \\
\hline \multicolumn{3}{|l|}{ Adjusted } \\
\hline $\begin{array}{l}\text { CKD-EPI creatinine-cystatin C } \\
\text { (mL/min) }\end{array}$ & \multicolumn{2}{|c|}{ Mean \pm SE } \\
\hline Baseline & $106.0 \pm 4.3$ & $110.4 \pm 4.9$ \\
\hline 3 months & $109.2 \pm 3.9^{\star *}$ & $112.4 \pm 4.7$ \\
\hline 6 months & $100.9 \pm 3.7$ & $107.1 \pm 4.3$ \\
\hline$P$-value time $=0.020$ & $P$-value intervention $=0.289$ & $P$-value interaction $=0.830$ \\
\hline \multicolumn{3}{|c|}{$\begin{array}{l}\text { Abbreviations: } \mathrm{BMI}=\text { body mass index; } 25(\mathrm{OH}) \mathrm{D}=25 \text {-hydroxy vitamin } \mathrm{D} ; \mathrm{A} 1 \mathrm{c}=\text { glycated hemoglobin; } \mathrm{CKD}-\mathrm{EPI}=\mathrm{Chronic} \\
\text { Kidney Disease Epidemiology Collaboration; } \mathrm{SE}=\text { standard error. }{ }^{*} \text { Represents significant differences from baseline; } \\
{ }^{*} \text { represents significant differences from } 3 \text { to } 6 \text { months. } \\
\text { Adjustment variables: BMI, known years with diabetes, A1c, diabetes medications, blood pressure medications, } \\
25(\mathrm{OH}) \mathrm{D} \text {, vitamin D intake, sun exposure. Data reported as Mean } \pm S E \text {. P is considered significant at }<0.05 \text {. }\end{array}$} \\
\hline
\end{tabular}


Hypothesis 4: Vitamin $D_{3}$ supplementation at $6,000 \mathrm{lU} / \mathrm{d}$ will be more effective than the $4,000 \mathrm{IU} / \mathrm{d}$ over 6 months in lowering microalbuminuria measured by first morning urine samples.

Unadjusted and Adjusted linear mixed models showed that the effect of time $[(p=0.889)$ and $(p=0.954)]$, intervention $[(p=0.254)$ and $(p=0.425)]$ and the interaction between time and intervention $[(p=0.370$ and $(p=0.435)]$ on microalbuminuria were not statistically significant within and between 4,000 $\mathrm{IU} / \mathrm{d}$ and 6,000 IU/d groups, respectively (Table 7). 
Table 7. Unadjusted and Adjusted Intervention Groups Comparisons of Microalbuminuria at Different Time Points

\begin{tabular}{|c|c|c|}
\hline \multirow[b]{2}{*}{ Unadjusted } & \multicolumn{2}{|c|}{ Intervention } \\
\hline & $\begin{array}{c}4,000 \mathrm{IU} / \mathrm{d} \\
n=39\end{array}$ & $\begin{array}{c}6,000 \mathrm{IU} / \mathrm{d} \\
n=24\end{array}$ \\
\hline MAU (mg/dL) & \multicolumn{2}{|c|}{ Mean \pm SE } \\
\hline Baseline & $4.5 \pm 2.4$ & $6.8 \pm 3.0$ \\
\hline 3 months & $3.1 \pm 1.9$ & $8.1 \pm 2.5$ \\
\hline 6 months & $3.5 \pm 1.8$ & $7.0 \pm 2.3$ \\
\hline$P$-value time $=0.889$ & $P$-value intervention $=0.254$ & $P$-value interaction $=0.370$ \\
\hline \multicolumn{3}{|l|}{ Adjusted } \\
\hline MAU (mg/dL) & \multicolumn{2}{|c|}{ Mean \pm SE } \\
\hline Baseline & $4.5 \pm 2.9$ & $5.9 \pm 3.5$ \\
\hline 3 months & $3.5 \pm 2.3$ & $7.5 \pm 2.8$ \\
\hline 6 months & $3.9 \pm 2.2$ & $6.7 \pm 2.5$ \\
\hline$P$-value time $=0.954$ & $P$-value intervention $=0.425$ & $P$-value interaction $=0.435$ \\
\hline
\end{tabular}

Abbreviations: $\mathrm{BMI}=$ body mass index; $25(\mathrm{OH}) \mathrm{D}=25$-hydroxy vitamin $\mathrm{D} ; \mathrm{A} 1 \mathrm{c}=$ glycated hemoglobin; MAU=microalbuminuria; $\mathrm{SE}=$ standard error.

Adjustment variables: age gender, BMI, known years with diabetes, A1c, diabetes medications, blood pressure medications, $25(\mathrm{OH}) \mathrm{D}$, vitamin D intake, sun exposure. Data reported as Mean \pm SE. $P$ is considered significant at $<0.05$. 
Aim 2: To evaluate the effect of vitamin $D_{3}$ supplementation at 6,000 IU/d vs. 4,000 IU/d on markers of cardiovascular disease risk among Hispanics and African Americans with type 2 diabetes and hypovitaminosis $D(<30 \mathrm{ng} / \mathrm{ml})$.

Hypothesis 1: Vitamin $D_{3}$ supplementation at 6,000 IU/d will be more effective than the 4,000 IU/d over 6 months in lowering systolic and diastolic blood pressure levels.

Unadjusted mixed models showed marginally significant effect of time $(p=0.080)$ and significant effect of intervention $(p=0.001)$ on systolic blood pressure. A significant effect of the interaction between time and intervention $(p=0.032)$ was observed. LSD post-hoc analyses indicated that systolic blood pressure levels significantly decreased from baseline $(146.2 \pm 4.0 \mathrm{mmHg})$ to 3 months $(139.8 \pm 3.3 \mathrm{mmHg}, \mathrm{p}=0.035)$ and significantly higher decrease at 6 months $(135.0 \pm 3.5 \mathrm{mmHg}, \mathrm{p}=0.003)$ only in the $6,000 \mathrm{IU} / \mathrm{d}$ vitamin $\mathrm{D}$ group. Additionally, significant differences were observed in systolic blood pressure levels between 4,000 IU/d and 6,000 IU/d groups at 3 months [(126.5 $22.6 \mathrm{mmHg}$ vs. $139.8 \pm 3.3 \mathrm{mmHg}, \mathrm{p}=0.002)]$ (Table 8 ).

Adjusted linear mixed models showed no significant effect of time on systolic blood pressure $(p=0.490)$. However, the effect of intervention $(p=0.006)$ and the interaction between time and intervention $(p=0.026)$ were statistically significant. Post-hoc LSD analyses showed a significant decreased in 
mean systolic blood pressure levels from baseline $(144.1 \pm 4.0 \mathrm{mmHg})$ to 6 months $(134.5 \pm 3.5 \mathrm{mmHg}, \mathrm{p}=0.020)$ only for the $6,000 \mathrm{IU} / \mathrm{d}$ group. Furthermore, a marginal decrease in systolic blood pressure levels were observed in the 6,000 IU/d group from 3 months $(139.9 \pm 3.4 \mathrm{mmHg})$ to 6 months $(134.5 \pm 3.5 \mathrm{mmHg}$, $p=0.088)$. Significant differences between intervention groups $(4,000 \mathrm{IU} / \mathrm{d}$ vs. $6,000 \mathrm{lU} / \mathrm{d})$ in systolic blood pressure levels were found at 3 months $(128.5 \pm 2.6$ mmHg vs. $139.9 \pm 3.4 \mathrm{mmHg}, \mathrm{p}=0.007$ ) but not in 6 months (Table 8).

Unadjusted mixed models indicated that the effect of intervention on diastolic blood pressure was statistically significant $(p=0.003)$. However, the effect of time $(p=0.538)$ or the interaction between time and intervention $(p=0.110)$ were not statically significant. LSD post-hoc analyses indicated that changes in diastolic blood pressure levels were marginally significant from baseline $(91.8 \pm 2.2 \mathrm{mmHg})$ to 6 months $(87.9 \pm 2.0 \mathrm{mmHg}, \mathrm{p}=0.055)$ in the 6,000 IU/d group. Additionally, significant differences in mean diastolic blood pressure levels were observed at 3 months $(83.2 \pm 1.5 \mathrm{mmHg}$ vs. $89.3 \pm 1.9 \mathrm{mmHg}$, $\mathrm{p}=0.015)$ and marginally significant at 6 months $(83.5 \pm 1.5 \mathrm{mmHg}$ vs. $87.9 \pm 2.0$ $\mathrm{mmHg}, \mathrm{p}=0.086$ ) (Table 8).

Adjusted linear mixed models analysis showed that the effect of intervention on diastolic blood pressure was statistically significant $(p=0.004)$; however, the effect of time $(p=0.703)$ or the interaction of between time and intervention ( $p=0.108)$ were not significant. Post-hoc LSD analyses revealed 
marginally significant decrease in mean diastolic blood pressure levels from baseline values $(91.3 \pm 2.6 \mathrm{mmHg})$ to 6 months $(87.3 \pm 2.2 \mathrm{mmHg}, \mathrm{p}=0.086)$ only for the 6,000 IU/d group. Significant differences between intervention groups $(4,000 \mathrm{lU} / \mathrm{d}$ vs. $6,000 \mathrm{IU} / \mathrm{d})$ in diastolic blood pressure levels were observed at 3 months $(82.7 \pm 1.9 \mathrm{mmHg}$ vs. $88.7 \pm 2.2 \mathrm{mmHg}, \mathrm{p}=0.017)$ (Table 8 ). 
Table 8. Unadjusted and Adjusted Intervention Groups Comparisons of Blood Pressure at Different Time Points

\begin{tabular}{|c|c|c|}
\hline \multirow[b]{2}{*}{ Unadjusted } & \multicolumn{2}{|c|}{ Intervention } \\
\hline & $\begin{array}{c}4,000 \mathrm{IU} / \mathrm{d} \\
\mathrm{n}=39\end{array}$ & $\begin{array}{c}6,000 \mathrm{IU} / \mathrm{d} \\
\mathrm{n}=24\end{array}$ \\
\hline Systolic blood pressure (mmHg) & \multicolumn{2}{|c|}{ Mean士SE } \\
\hline Baseline & $126.8 \pm 3.1$ & $146.2 \pm 4.0$ \\
\hline 3 months & $126.5 \pm 2.6^{\dagger}$ & $139.8 \pm 3.3^{*}$ \\
\hline 6 months & $127.9 \pm 2.7$ & $135.0 \pm 3.5^{\star}$ \\
\hline$P$-value time $=0.080$ & $P$-value intervention $=0.001$ & $P$-value interaction $=0.032$ \\
\hline \multicolumn{3}{|l|}{ Diastolic blood pressure $(\mathrm{mmHg})$} \\
\hline Baseline & $82.3 \pm 1.7$ & $91.8 \pm 2.2$ \\
\hline 3 months & $83.2 \pm 1.5^{\dagger}$ & $89.3 \pm 1.9$ \\
\hline 6 months & $83.5 \pm 1.5$ & $87.9 \pm 2.0$ \\
\hline$P$-value time $=0.538$ & $P$-value intervention $=0.003$ & $P$-value interaction $=0.110$ \\
\hline \multicolumn{3}{|l|}{ Adjusted } \\
\hline Systolic blood pressure (mmHg) & \multicolumn{2}{|c|}{ Mean \pm SE } \\
\hline Baseline & $127.1 \pm 3.3$ & $144.1 \pm 4.0$ \\
\hline 3 months & $128.5 \pm 2.6^{\dagger}$ & $139.9 \pm 3.4$ \\
\hline 6 months & $130.3 \pm 2.8$ & $134.5 \pm 3.5^{\star}$ \\
\hline$P$-value time $=0.490$ & $P$-value intervention $=0.006$ & $P$-value interaction $=0.026$ \\
\hline \multicolumn{3}{|l|}{ Diastolic blood pressure $(\mathrm{mmHg})$} \\
\hline Baseline & $81.7 \pm 2.2$ & $91.3 \pm 2.6$ \\
\hline 3 months & $82.7 \pm 1.9+$ & $88.7 \pm 2.2$ \\
\hline 6 months & $82.9 \pm 1.9$ & $87.3 \pm 2.2$ \\
\hline$P$-value time $=0.703$ & $P$-value intervention $=0.004$ & $P$-value interaction $=0.108$ \\
\hline
\end{tabular}

Abbreviations: $\mathrm{BMI}=$ body mass index; $25(\mathrm{OH}) \mathrm{D}=25$-hydroxy vitamin $\mathrm{D} ; \mathrm{A} 1 \mathrm{c}=$ glycated hemoglobin; SE=standard error. ${ }^{*}$ Represents significant differences from baseline; ${ }^{\dagger}$ represents significant differences at 3 months between intervention groups. Adjustment variables: age gender, BMI, known years with diabetes, A1c, diabetes medications, blood pressure medications, $25(\mathrm{OH}) \mathrm{D}$, vitamin $\mathrm{D}$ intake, sun exposure. Data reported as Mean $\pm S E$. $P$ is considered significant at $<0.050$. 


\section{CHAPTER IV: DISCUSSION}

\section{Serum 25-hydroxy vitamin D}

The study focused on vitamin $D_{3}$ supplementation interventions for Hispanics and Blacks with hypovitaminosis D and type 2 diabetes. All participants in our study had $25(\mathrm{OH}) \mathrm{D}$ levels below $30 \mathrm{ng} / \mathrm{mL}$ at baseline. Our findings showed that vitamin $\mathrm{D}_{3}$ supplementation noticeably increased $25(\mathrm{OH}) \mathrm{D}$ levels in both intervention groups which indicated that the supplement doses were adequately bioavailable, well absorbed and tolerated by the participants. It was expected that serum 25(OH)D levels would improve at 6 months in both groups; however, we found no significant differences between the $4,000 \mathrm{IU} / \mathrm{d}$ and 6,000 IU/d groups at the end of the study. Despite the high doses of vitamin $D_{3}$ used in this study, there were no adverse events or signs of toxicity reported by any of the participants throughout the study.

Several previous studies are available where vitamin $D_{3}$ (cholecalciferol) was used to replenish serum 25(OH)D levels. Kim et al. (2011), used supplementation with vitamin $D_{3}$ for participants with serum vitamin $D$ deficiency ( $\leq 16 \mathrm{ng} / \mathrm{ml}$ ) with 40,000 IU/week for 8 weeks and 40,000 IU/month for additional 8 weeks; and participants with vitamin D insufficiency $(16-32 \mathrm{ng} / \mathrm{mL})$ with 40,000 IU/month. They found significantly increased mean serum 25(OH)D levels from baseline $(15.6 \pm 7.0 \mathrm{ng} / \mathrm{mL})$ to 4 months $(39.7 \pm 12.8 \mathrm{ng} / \mathrm{ml})$ in individuals with type 2 diabetes. In our study, mean 25(OH)D levels at baseline were $20.7 \mathrm{ng} / \mathrm{mL}$ for the $4,000 \mathrm{IU} / \mathrm{d}$ group and $21.7 \mathrm{ng} / \mathrm{mL}$ for the $6,000 \mathrm{IU} / \mathrm{d}$. By the end of the 
intervention (6 months), mean 25(OH)D levels increased to sufficient levels 37.9 $\mathrm{ng} / \mathrm{mL}$ for the $4,000 \mathrm{IU} / \mathrm{d}$ group and $38.9 \mathrm{ng} / \mathrm{mL}$ for the $6,000 \mathrm{IU} / \mathrm{d}$ group. In another study, individuals were supplemented with the equivalent of $10,000 \mathrm{IU} / \mathrm{d}$ for 3 months, mean 25(OH)D levels significantly increased $($ pre-intervention = $13.4 \mathrm{ng} / \mathrm{mL}$ to post-intervention $=82.8 \mathrm{ng} / \mathrm{mL}$ ). Conversely, there are studies where vitamin $\mathrm{D}_{3}$ supplementation did not replenish serum 25(OH)D levels above (30 ng/mL). These studies used doses of vitamin $D_{3}$ supplementation $\leq 1000 \mathrm{IU} / \mathrm{d}$ or the equivalent (Oksa et al., 2008 and Rucker et al., 2009).

The Institute of Medicine (IOM) guidelines (Institute of Medicine, 2011) specified that the Recommended Dietary Allowance (RDA) for $>97.5 \%$ of the population for vitamin $D$ intake is $600-800 \mathrm{IU} / \mathrm{d}$. In our study, none of the participants met the RDA for vitamin $D$ for their age, the mean vitamin $D$ intake was $127.0 \pm 82.7 \mathrm{IU}$ for the $4,000 \mathrm{IU} / \mathrm{d}$ group and $122.2 \pm 86.4 \mathrm{IU}$ for the $6,000 \mathrm{IU} / \mathrm{d}$ group (Table 1). Nevertheless, greater dosages than the RDA of vitamin D intake are needed it to replenish those with deficient and insufficient $25(\mathrm{OH}) \mathrm{D}$ levels. We investigated the effect of vitamin $\mathrm{D}_{3}$ supplementation using the IOM (Institute of Medicine, 2011) recommended tolerable upper intake level $(4,000$ $\mathrm{IU} / \mathrm{d})$ and a higher dose $(6,000 \mathrm{IU} / \mathrm{d})$; however, the IOM recommendations for vitamin $\mathrm{D}$ are not formulated for those with preexisting conditions (such as diabetes). The Endocrine Society Clinical Practice Guideline advise that individuals with $25(\mathrm{OH}) \mathrm{D}$ levels below $20 \mathrm{ng} / \mathrm{mL}$ be supplemented with vitamin $\mathrm{D}_{3}$ $(6,000 \mathrm{IU} / \mathrm{d})$ for eight weeks to restore normal vitamin D levels above $30 \mathrm{ng} / \mathrm{mL}$. 
After reaching sufficiency, vitamin $\mathrm{D}_{3}$ supplementation needs to be continued by a maintenance phase of $1,500-2,000 \mathrm{IU} / \mathrm{d}$. Due to the high prevalence of vitamin D deficiency/insufficiency in individuals with type 2 diabetes, achieving normal 25(OH)D levels should be considered an important therapeutic goal. The amount of vitamin $D_{3}$ necessary to achieve adequate serum 25(OH)D levels for populations with multiple chronic conditions has yet to be established and may be confounded by variations in geographic region, seasons, skin color, sun exposure, race/ethnicity, diet, and body fat. The optimal 25(OH)D level that would have a clinical effect on health risk outcomes remains to be defined.

Our study did not include a placebo or control arm, since the intervention groups were not recruited and conducted in parallel and due to the inclusion criterion, we included individuals with $25(\mathrm{OH}) \mathrm{D}$ levels with deficiency/insufficiency $(<30 \mathrm{ng} / \mathrm{mL})$. Ethically it was not appropriate or advisable to treat vitamin D deficient/insufficient participants with placebo for 6 months. Participants were not allowed to take any type or form of vitamin D supplement other than a multivitamin, and we encouraged them to not change their dietary and sun exposure habits during the study. The high doses of vitamin $D_{3}$ used in this study were not only intended to replenish serum $25(\mathrm{OH}) \mathrm{D}$ levels but also to improve study outcomes (kidney and cardiovascular disease markers). 


\section{Glomerular Filtration Rate (GFR)}

Studies showed that diabetes and kidney disease are associated with low 25(OH)D levels (Husemoen et al., 2012; Levin et al., 2007). Existing data indicate the relationship between hypovitaminosis $D$ and mortality in individuals with chronic kidney disease (CKD) (Navaneethan et al., 2011). CKD is a predictor of vitamin $\mathrm{D}$ insufficiency/deficiency because the kidney is involved in the metabolism of vitamin D (Echida et al., 2012). Findings from our study suggest the possible beneficial role of vitamin $\mathrm{D}_{3}$ supplementation on kidney function biomarkers in individuals with type 2 diabetes. Our study showed that individuals with type 2 diabetes had significantly improved kidney function by increasing CKD-EPI creatinine equation over time (pre-intervention $=84.6 \pm 18.4$ $\mathrm{mL} / \mathrm{min}$ - post-intervention $=92.4 \pm 18.9 \mathrm{~mL} / \mathrm{min}$ ) in the $4,000 \mathrm{IU} / \mathrm{d}$ group and (pre-intervention $=94.2 \pm 17.5 \mathrm{~mL} / \mathrm{min}$ to post-intervention $=97.9 \pm 18.0 \mathrm{~mL} / \mathrm{min}$ ) in the 6,000 IU/d group. The effect of vitamin $\mathrm{D}_{3}$ supplementation on markers of kidney function persisted after adjusting for major confounding variables only on the $4,000 \mathrm{IU} / \mathrm{d}$ group. This could be due to small number of participants in the 6,000 IU/d group ( $n=24)$ and higher CKD-EPI creatinine values at baseline as compared to the $4,000 \mathrm{IU} / \mathrm{d}$. On the other hand, CKD-EPI creatinine - cystatin C equation indicated significant decrease over time (pre-intervention $=112.6 \pm 21.5$ $\mathrm{mL} / \mathrm{min}$ to post-intervention $=98.6 \pm 24.0 \mathrm{~mL} / \mathrm{min}$ ) in the $4,000 \mathrm{IU} / \mathrm{d}$ group. There are several possible explanations for the different results from the eGFR equations. The study by Fan et al. (2014) compared the effectiveness of eGFR equations: CKD-EPI creatinine and CKD-EPI creatinine - cystatin C. Results 
showed that CKD-EPI creatinine equation underestimated more individuals with elevated $\mathrm{BMI}$ as compared to the CKD-EPI creatinine - cystatin $\mathrm{C}$ equation. The CKD-EPI creatinine - cystatin C equation was more precise than CKD-EPI creatinine while estimating GFR values for those with diabetes and obesity. However, the study by Fan et al. (2014) have limitations. Pooled analyzed data from that study cannot distinguish between individuals with type 1 or type 2 diabetes, the approaches used to estimate glomerular filtration rate, or factors that affected creatinine values.

In a longitudinal study with a follow-up of over 4 years $(n=1705)$ (De Boer et at., 2011), lower $25(\mathrm{OH}) \mathrm{D}$ levels were linked a faster change in eGFR rate loss among older adults, especially for those with $25(\mathrm{OH}) \mathrm{D}$ level below $15 \mathrm{ng} / \mathrm{mL}$, diabetes and hypertension. Vitamin $\mathrm{D}_{3}$ supplementation $(666 \mathrm{lU} / \mathrm{d})$ for 6 months did not significantly change in eGFR values in either the intervention or control group and non-significant differences were found between study groups with CKD stages 3-4 (Molina et al., 2014). Vitamin $\mathrm{D}_{3}$ supplementation of $1000 \mathrm{IU} / \mathrm{d}$ versus a control for Canadian adults with later stages (3-5) of kidney disease study found no improvements in kidney function (GFR and albuminuria). Negative findings could be due to the mean $25(\mathrm{OH}) \mathrm{D}$ levels post-intervention being below the $30 \mathrm{ng} / \mathrm{mL}$ sufficiency and short duration of the supplementation (3 months) (Rucker et al., 2009). Two additional studies by Kim et al. (2011) and Basturk et al. (2011) found no significant changes in eGFR after vitamin $D_{3}$ supplementation. All the studies reported included participants in the later stages 
of CKD 3-5 contrary to our study where we included participants with early stages of CKD (1-3). Early supplementation with vitamin $\mathrm{D}_{3}$ might provide a more valuable treatment and possibly delaying adverse kidney disease outcomes.

The National Kidney Foundation clinical guidelines indicated that individuals with CKD stages 3-4 and serum 25(OH)D levels $(<30 \mathrm{ng} / \mathrm{mL})$ to be treated with vitamin $D_{2}$ instead of vitamin $D_{3}$ (National Kidney Foundation, 2003). At the time (year 2003) when this guideline was written no controlled clinical studies were available comparing the safety and efficacy of vitamin $D_{2}$ versus vitamin $D_{3}$. Additionally, access to commercial high doses up to 50,000 IU are available for vitamin $D_{2}$ (Houghton and Vieth, 2006). The dosage recommendation by the National Kidney Foundation clinical guidelines is according to the vitamin $D$ status. Individuals with vitamin D deficiency [serum 25(OH)D levels $(<5 \mathrm{ng} / \mathrm{mL}$ and 5-15 ng/mL)] should receive 50,000 IU/week for 4-12 weeks and then same dose monthly for 6 months. Individuals with vitamin D insufficiency [serum 25(OH)D levels $16-30 \mathrm{ng} / \mathrm{mL})]$ should receive $50,000 \mathrm{IU} / \mathrm{month}$ for 6 months (National Kidney Foundation, 2003). Nevertheless, previous studies demonstrated that supplementation with vitamin $D_{2}$ were less consistent in reaching ideal serum $25(\mathrm{OH}) \mathrm{D}$ levels $\left(>30 \mathrm{mg} / \mathrm{mL}\right.$ ) as compared to vitamin $\mathrm{D}_{3}$ (Houghton and Vieth, 2006; Armas et al., 2004; Heaney et al., 2011). Several studies found a reduction in kidney disease markers using vitamin $D$ analogues (paricalcitol) (Alborzi et al., 2008; de Zeeuw et al., 2010; Fishbane et al., 2009); however, vitamin $D_{3}$ has been shown to be equally effective. The equal 
effectiveness of vitamin $D_{3}$ may be of importance since hypercalcemia has been observed with some vitamin D analogues (Moe et al, 2009). Vitamin D analogues are biologically active and individuals using them need to be monitored for hypercalcemia and hyperphosphatemia more closely than with vitamin $D_{3}$ (Kandula et al., 2011). There are no formal recommendations for vitamin $D_{3}$ supplementation for individuals with early CKD by the National Kidney Foundation. Still clarification and a more precise definition needs to be implemented for the vitamin $\mathrm{D}_{3}$ supplementation dosage, frequency, serum 25(OH)D levels before intervention starts, and whether complications from kidney dysfunction can be prevented. Therefore, available guidelines from Kidney Disease Outcomes Quality Initiative (KDOQI) needs to be revised.

Current study contributes to the scientific knowledge for understanding of the role of vitamin $D_{3}$ supplementation on kidney function among minority groups. Early interventions could delay progression of the disease which would have a profound effect on lowering health care costs and burden to society as well as improving the quality of life (Jungers, 2002). Medical costs were doubled for individuals with kidney disease from a large Health Maintenance Organization (HMO) as compared to those without kidney disease (Smith et al., 2004). Therefore, approaches to manage kidney disease such as vitamin $D_{3}$ supplementation are important in clinical practice. 


\section{Microalbuminuria}

Reduction of urinary albumin levels is an important therapeutic goal that slow the progression of kidney dysfunction. Previous studies indicated that microalbuminuria was associated with cardiovascular disease and mortality in individuals with type 2 diabetes (Mogensen, 1984; Valmadrid et al., 2000). Microalbuminuria, abnormal increase in urinary albumin excretion, is an early sign of kidney dysfunction (Mogensen, 1984). In a prospective population-based study, individuals with type 2 diabetes $(n=1,253)$ were followed for 7 years, microalbuminuria was linked to a $42 \%$ increase in the progression to nephropathy (Bruno et al., 2003). The usual course of microalbuminuria is progressive in individuals with type 2 diabetes (Bruno et al., 2003); therefore, early screening and treatment of microalbuminuria can reduce the risk for kidney dysfunction and possibly decrease the burden associated with diabetes complications.

Several studies found an inverse association between 25(OH)D levels and albuminuria (de Boer et al., 2007; Skaaby et al., 2013; Isakova et al., 2011). Data from NHANES III that included $(n=15,068)$ participants, found an inverse association between 25(OH)D levels and prevalence of albuminuria (de Boer et al., 2007). Furthermore, after excluding participants with macroalbuminuria from the statistical analysis, significant similar results were also found for microalbuminuria (de Boer et al., 2007). In a five-year follow-up study of a random sample of Caucasians $(n=4,330)$, aged 30-60 years, low 25(OH)D levels 
predicted higher urinary protein excretion (Skaaby et al., 2013). Hypovitaminosis D frequently occurs in minorities groups, especially in those with type 2 diabetes and kidney dysfunction. The clinical implications of monitoring microalbuminuria and 25(OH)D levels among individuals with type 2 diabetes may delay future adverse complications, especially among individuals with other concomitant conditions (i.e. hypertension).

In our study, microalbuminuria did not improve over time by either dose of vitamin $D_{3}$ supplementation. The findings from several studies corroborate our study results. In a randomized, double blind, clinical trial, fifty-two individuals [hemodialysis treated $(n=27) /$ non-hemodialysis treated $(n=25)$ ] with serum 25(OH)D levels $<20 \mathrm{ng} / \mathrm{mL}$ received vitamin $\mathrm{D}_{3}$ supplementation $(40,000$ IU/week) or placebo. After 8 weeks, vitamin $D_{3}$ supplementation did not significantly change urinary protein excretion (Marckmann et al., 2012). Urinary protein excretion showed no significant improvements in a Brazilian cohort $(n=45)$ with CKD stages 3-4 that were supplemented with vitamin $D_{3}(50,000$ IU/week) for 6 months (Garcia-Lopes et al., 2012). In contrast, several studies described that vitamin $D_{3}$ supplementation reduce albuminuria. In a prospective study, individuals ( $n=63$ ) with type 2 diabetes and CKD stages 2-4 were given vitamin $D_{3}$ supplementation according to their serum vitamin $D$ status. Results showed a reduction of albuminuria for those receiving vitamin $D_{3}$ supplementation (Kim et al., 2011). In the study by Molina et al. (2014), Caucasian older adult participants $(n=101)$ with advance CKD (stages 3-4) 
received either vitamin $D_{3}$ supplementation $(666 \mathrm{IU} / \mathrm{d}$ ) or placebo for 6 months. Urinary albumin-to-creatinine ratio significantly decreased only in participants who received vitamin $D_{3}$ supplementation. Improving kidney function in individuals with type 2 diabetes play a vital role in preventing cardiovascular disease and development of end-stage renal disease (ESRD).

\section{Blood Pressure}

This study demonstrated that vitamin $\mathrm{D}_{3}$ supplementation improved systolic blood pressure in the higher dose group $(6,000 \mathrm{IU} / \mathrm{d})$. Our study found a reduction in systolic blood pressure of approximately $11 \mathrm{mmHg}$ (pre-intervention= 146.2 $\pm 22.1 \mathrm{mmHg}-$ post-intervention $=135.0 \pm 17.8 \mathrm{mmHg}$ ) by the end of the 6 months' intervention. Results of this study are consistent with some previous studies. A randomized, double-blind, clinical trial investigated the effect oral vitamin $\mathrm{D}_{3}$ cholecalciferol $(50,0000 \mathrm{IU} /$ per week) on blood pressure among individuals with type 2 diabetes ( $n=30$ intervention/ $n=30$ placebo). Thirty-two participants in the study had either serum 25(OH)D levels classified as deficient $(n=5)$ or insufficient $(n=27)$. Vitamin $D_{3}$ supplementation (50,000 IU per week)

reduced systolic and diastolic blood pressure from baseline $(121.0 \pm 13.0 \mathrm{mmHg}$ and $80.5 \pm 8.0 \mathrm{mmHg})$ to 12 weeks' follow-up $(110.0 \pm 9.0 \mathrm{mmHg}, \mathrm{p}=0.001$ and $76.3 \pm 7.0 \mathrm{mmHg}, p=0.046$ respectively), only in the intervention group (Nasri et al., 2014). The efficacy of 8 weeks of vitamin $D_{3}(800 \mathrm{lU} / \mathrm{d})$ and calcium supplementation (1200 mg) vs. calcium supplementation $(1200 \mathrm{mg} / \mathrm{d})$ on blood pressure was measured on elderly women $(n=148)$ with $25(O H) D$ levels below 
(20 ng/mL). A significant reduction in systolic blood pressure of $9.3 \%$

[(baseline $=144.1 \pm 20.4 \mathrm{mmHg})$ and $(8$-week follow-up=131.0 $\pm 16.9 \mathrm{mmHg})]$ was found in the intervention with vitamin $D_{3}$ and calcium group as compared to calcium alone group [(baseline $=140.6 \pm 14.7 \mathrm{mmHg})$ and $(8$-week follow-up= $134.9 \pm 19.9 \mathrm{mmHg})]$; however, no significant decrease in diastolic blood pressure was found (Pfeifer et al., 2001). Another study (Sugden et al., 2008) investigated the effect of vitamin $D_{2}(100,000$ single oral dose) supplementation vs. placebo on blood pressure in individuals with type 2 diabetes and low 25(OH)D $(<20$ $\mathrm{ng} / \mathrm{mL})$. After 8-week follow-up, participants in the vitamin $D_{2}$ group $(n=17)$ had reduced systolic blood pressure by $14 \mathrm{mmHg}$ compared to those in the placebo group ( $n=17)$; however, no significant changes were found for diastolic blood pressure.

In contrast, results from other studies found no improvements in blood pressure after vitamin $D_{3}$ supplementation. Findings from the DAYLIGHT trial, a double-blind, randomized controlled study, which included $(n=534)$ participants with age range of $18-50$ years old, $25(\mathrm{OH}) \mathrm{D}$ levels $(\leq 25 \mathrm{ng} / \mathrm{ml})$, and prehypertension and/or untreated stage 1 hypertension indicated no beneficial effect of vitamin $D_{3}$ supplementation groups (400 IU/d or $4,000 \mathrm{lU} / \mathrm{d}$ ) on systolic or diastolic blood pressure after 6 months of intervention (Arora et al., 2014). This study is one of the largest sampled (46\% Whites, $48 \%$ Blacks and $6 \%$ other ethnicity) clinical trial conducted were the primary endpoint was blood pressure. In a randomized controlled, double-blind clinical trial, vitamin $\mathrm{D}_{3}$ supplementation 
(a single oral dose of $100,000 \mathrm{IU}$ ) did not significantly reduce blood pressure during the 5 -week duration in elderly adults during winter ( $n=95$ intervention group, $n=94$ placebo group) (Scragg et al., 1995). Vitamin $D_{3}$ supplementation (Schleithoff et al., 2006) (intervention group, $n=42,2000 \mathrm{IU}+$ Calcium $500 \mathrm{mg} / \mathrm{d}$ ) or (placebo group, $\mathrm{n}=51$, placebo $+500 \mathrm{mg}$ calcium/d) did not change systolic or diastolic blood pressure after 9 months' intervention in individuals with congestive heart failure. In the Women's Health Initiative Randomized Trial (Margolis et al., 2008), postmenopausal women $(n=36282)$ were given vitamin $D_{3}(400 \mathrm{lU} / \mathrm{d})+$ calcium $(1000 \mathrm{mg} / \mathrm{d})$ or placebo. After a median of 7-year follow-up, there were no significant differences between the intervention and placebo groups in systolic or diastolic blood pressure. A randomized double-blind clinical trial with 1-year duration (Zittermann et al., 2009), provided vitamin $D_{3}$ (3320 IU/d - 5 drops of oily vitamin D) or placebo (5 drops of vitamin D-free oil) to $n=200$ healthy overweight individuals with mean $25(\mathrm{OH}) \mathrm{D}$ levels of $12 \mathrm{ng} / \mathrm{mL}$ ( $\mathrm{n}=100$ each group). Results from this study showed no significant time and intervention interaction effects for systolic or diastolic blood pressure. Jorde et al. (2010) conducted double-blind clinical randomized clinical trial including 438 overweight or obese participants using two dosages of vitamin $\mathrm{D}_{3}$ and placebo. One vitamin $\mathrm{D}_{3}$ group received 40,000 IU/week, the second vitamin $D_{3}$ group received 20,000 IU/week and the third group received placebo. Additionally, all vitamin $\mathrm{D}_{3}$ groups and placebo received $500 \mathrm{mg}$ of calcium/d. After 1-year of intervention, findings do not support the efficacy of vitamin $\mathrm{D}_{3}$ supplementation in reducing blood pressure. 
Inconsistent findings from these clinical trials could be due to: 1) studies were conducted and/or analyzed using different ranges of vitamin D supplementation alone or combined with calcium; 2) age range and gender of the participants; 3) duration of the studies; 4) comorbidities and ethnic background of the participants and 5) covariates included in the statistical analyses (Pittas et al., 2010; Witham et al., 2009; Jorde et al., 2010; Beveridge et al., 2015; Larsen et al., 2012; Witham et al., 2010; Forman et al., 2013; Pfeifer et al., 2001; Sugden et al., 2008; Margolis et al. 2008). In our study, significant differences in blood pressure at baseline between vitamin $\mathrm{D}_{3}$ supplementation groups $(4,000 \mathrm{IU}$ vs. $6,000 \mathrm{IU} / \mathrm{d}$ ) could have make the interpretation of findings complex. The 6,000 IU/d vitamin $D_{3}$ group started with significantly higher levels of systolic and diastolic blood pressure as compared to the $4,000 \mathrm{IU} / \mathrm{d}$ group. On the other hand, the $4,000 \mathrm{IU} / \mathrm{d}$ had a higher percentage of participants on hypertension medications at baseline. We cannot dismiss that hypertensive medications might have contributed to the decrease in blood pressure levels in either intervention group. Nevertheless, throughout the duration of the study any medication change by the participants were recorded and adjustment for medications were taken into consideration in the statistical analysis. Those in the 4,000 IU/d group might benefited less from vitamin $\mathrm{D}_{3}$ supplementation because they had well-treated blood pressure levels. 
The mechanism on how vitamin D affects blood pressure is poorly understood. Nonetheless, it has been postulated that vitamin D could affect blood pressure by regulating through the renin-angiotensin-aldosterone (RAAS) system (Li et al., 2004; Pilz et al., 2009). Our study did not include RAAS as an outcome measurement.

Despite the high prevalence of both vitamin D deficiency/insufficiency and hypertension among our minority population groups, there are no efforts to establish preventive measures that could benefit individuals by screening for 25(OH)D levels and providing vitamin $\mathrm{D}_{3}$ supplementation. These results ought to encourage researches to further examine the clinical significance and implications of vitamin $\mathrm{D}_{3}$ supplementation on elevated blood pressure levels that could have benefits for individuals with type 2 diabetes. Because evidence is still inconclusive, our findings support the potential therapeutic role of vitamin $D_{3}$ supplementation as complementary treatment for blood pressure; however, more rigorous clinical trials with larger sample sizes are required before recommending vitamin $\mathrm{D}_{3}$ supplementation exclusively to treat hypertension. 


\section{CHAPTER V: SUMMARY AND CONCLUSIONS}

Vitamin D deficiency/insufficiency is still a public health concern particularly affecting minorities with type 2 diabetes; therefore, more public health awareness is required to prevent consequences of vitamin D deficiency/insufficiency by identifying potential risk factors and develop effective interventions. This clinical trial sought to clarify the effect of vitamin $\mathrm{D}_{3}$ supplementation on kidney function and cardiovascular disease markers which goes beyond the prevention of bone health. The study included a sample of Hispanics and African Americans with type 2 diabetes and hypovitaminosis $D$ who were given two high dosages of vitamin $\mathrm{D}_{3}$ supplementation $(4,000 \mathrm{IU} / \mathrm{d}$ and $6,000 \mathrm{IU} / \mathrm{d})$. Although, we found significant changes in kidney and cardiovascular disease markers, supplementation with vitamin $D_{3}$ longer than 6 months may be needed to determine sustained long term effects in kidney and cardiovascular disease markers. Vitamin $D_{3}$ supplements are relatively inexpensive and safe and can be used as adjunct treatment option to improve kidney function and decrease blood pressure and consequent cardiovascular disease. Individuals with type 2 diabetes and kidney dysfunction and high blood pressure could benefit from vitamin $D_{3}$ supplementation, especially those with low levels of serum $25(\mathrm{OH}) \mathrm{D}$ levels. Clinical recommendations should contain screening and monitoring of serum $25(\mathrm{OH}) \mathrm{D}$ levels: including the measurement of serum $25(\mathrm{OH}) \mathrm{D}$ as a routine assay for high risk populations to provide health care professionals with the information required to recommend and treat, as well as offering the appropriate resources as preventive health benefits. 
Our results have set the foundations for further examination of the mechanisms and metabolic pathways associating vitamin D status with kidney and cardiovascular disease. Further research could provide more appropriate means for translation of these findings into recommendations for individuals with CKD, hypertension and type 2 diabetes. The efficacy of vitamin $D_{3}$ supplementation as complementary therapy for CKD and blood pressure in minority and other ethnic groups needs further investigation in larger and longer duration randomized controlled trials. 


\section{CHAPTER VI: STRENGTHS AND LIMITATIONS}

\section{Strengths}

Major strengths of the study include: The study included two minority groups (Hispanics and Blacks) with high prevalence of serum 25(OH)D levels deficiency/insufficiency and type 2 diabetes. We tested the safety of vitamin $D_{3}$ supplementation at two high dose levels: 4,000 IU/d and 6,000 IU/d. Throughout the duration of the study, no adverse effects or signs of toxicity were observed [IOM tolerable upper limit intake $(4,000 \mathrm{IU} / \mathrm{d})]$ for 6 months. These two doses were safe and effective in increasing participant's serum $25(\mathrm{OH}) \mathrm{D}$ levels in a population sample who started the study with hypovitaminosis $D$. We had a low number of drop-outs [(in the 4,000 IU/d group, $\mathrm{n}=1$ ) and (in the 6,000 IU/d group, $n=5)$ ] and low non-compliance to the vitamin $D_{3}$ supplementation [(in the 4,000 $\mathrm{IU} / \mathrm{d}$ group $(\mathrm{n}=3)$, and in the 6,000 IU/d group $(\mathrm{n}=2)]$. We took in consideration several measurements and confounder variables that could affect the outcomes such as diet, sun exposure, body mass index (BMI), medications, years with diabetes where other studies were lacking. Our study recorded any medication change throughout the duration of the study and adjusted for that in the statistical analyses. We carefully selected the inclusion criteria to test our outcomes [(i.e. participants with serum 25(OH)D considered deficient and insufficient, CKD stages $1-3$, etc.]. For the statistical analyses, we used linear mixed models since we had a longitudinal data with unbalanced number of participants in each study group (in the 4,000 IU/d group, $n=39$ and in the 6,000 IU/d group, $n=24$ ). 


\section{Limitations}

This study had several limitations. The study sample was a convenience sample and was not randomly selected from the general adult population in Miami-Dade County; therefore, results of this study cannot be generalized or extrapolated to the entire U.S. adult population nor Miami-Dade County. Nonrandomized groups could create selection bias because of the non-random assignment. The advantage of this convenience sample was its large minority representation; it was recruited from two clinics that have culturally diverse populations in Miami-Dade County. The relatively small sample size and greater numbers of female participants were other limitations of the study. Additionally, not having sufficient number of participants prevented the investigators to measure differences between ethnic groups (only few Black participants), and the uneven numbers of participants in each vitamin $D_{3}$ supplementation group may have decreased the statistical power of the study. The study lacked a control group - changes observed in the pre- and post-test might be due not only to the supplementation with vitamin $\mathrm{D}_{3}$, but to other factors such as change in the diet, sun exposure, or vitamin D supplements; however, we assessed for changes in these parameters during the study. We did not assess which mechanisms underlining vitamin $\mathrm{D}_{3}$ function were acting in kidney disease or blood pressure and how they were affected or changed by supplementation. Although trained interviewers who were bilingual in English and Spanish were present to administer the questionnaires to assess dietary habits of vitamin $D$, participants might under- or overestimated their intakes. There was more than 
$50 \%$ of participants in each vitamin $\mathrm{D}_{3}$ supplementation group taking hypertension medications, which possibly influenced blood pressure outcome over time; however, changes in medications were recorded and medication usage was used as a control variable in the analysis. Additionally, we advised participants to keep their medication use constant during the duration of the study, as prescribed by their primary physician. Lastly, conclusions beyond the 6 months' supplementation could not be drawn to understand the impact of long term effects of vitamin $\mathrm{D}_{3}$ supplementation. Studies with longer duration of supplementation and follow-up maybe needed to see these effects of vitamin $D_{3}$ supplementation in this sample or other ethnic groups. 


\section{CHAPTER VII: FUTURE RESEARCH}

It will be important to comprehend the role and impact of high levels of vitamin $D_{3}$ supplementation in larger cohorts with different geographical and ethnic backgrounds. Additionally, it will be important to examine longitudinal trajectories of kidney and cardiovascular disease markers, especially in high risk populations with existing comorbidities. Further evidence will allow for a greater understanding of the influence of changes in serum 25(OH)D values on kidney function, cardiovascular disease markers and type 2 diabetes. Investigation of these mechanisms and metabolic pathways are critical for developing effective interventions for the translation of findings into recommendations for care among individuals with type 2 diabetes. As the source for future research, findings from this study may have public and clinical health implications that could contribute to the expansion of ethnic-tailored interventions to reduce health disparities and prevent the high incidence of these chronic diseases in minorities. 


\section{REFERENCES}

1. Abrahamson, M., Olafsson, I., Palsdottir, A., et al. (1990). Structure and expression of the human cystatin $\mathrm{C}$ gene. Biochemical Journal, 1;268(2):287-294.

2. Alborzi, P., Patel, N. A., Peterson, C., et al. (2008). Paricalcitol reduces albuminuria and inflammation in chronic kidney disease: A randomized double-blind pilot trial. Hypertension, 52:249-255.

3. Alvarez, J. A., Wasse, H., and Tangpricha, V. (2012). Vitamin D supplementation in pre-dialysis chronic kidney disease: A systematic review. Dermato-Endocrinology, 4(2):118-127.

4. American Kidney Fund. Kidney Disease Statistics. (2015). Available from: http://www.kidneyfund.org/assets/pdf/kidney-disease-statistics.pdf. Accessed 05/12/ 2016.

5. Armas, L. A., Hollis, B. W., and Heaney, R. P. (2004). Vitamin D2 is much less effective than vitamin D3 in humans. The Journal of Clinical Endocrinology \& Metabolism, 89:5387-5391.

6. Beveridge, L. A., Struthers, A. D., Khan, F., et al. (2015). D-PRESSURE Collaboration. Effect of Vitamin D Supplementation on Blood Pressure: A Systematic Review and Meta-Analysis Incorporating Individual Patient Data. JAMA Internal Medicine, 1;175(5):745-754. doi: 10.1001/jamainternmed.2015.0237.

7. Blalock, S. J., Norton, L. L., Patel, R. A., Cabral, K., and Thomas, C. L. (2003). Development and assessment of a short instrument for assessing dietary intakes of calcium and vitamin D. Journal of the American Pharmacists Association, 43:685-693.

8. Bruno, G., Merletti, F., Biggeri, A., et al. (2003). Progression to overt nephropathy in type 2 diabetes: the Casale Monferrato Study. Diabetes Care, 26(7):2150-2155.

9. Center for Disease Control and Prevention (CDC). (2012). Division of Diabetes Translation. Chronic kidney disease initiative projects. Available from: http://www.cdc.gov/diabetes/projects/kidney/about.htm. Accessed 1/14, 2013.

10. Center for Disease Control and Prevention (CDC). Racial/ethnic disparities in the awareness, treatment, and control of hypertensionUnited States, 2003-2010. (2013). Available from: 
http://www.cdc.gov/mmwr/preview $/ \mathrm{mmwrhtml} / \mathrm{mm} 6218 \mathrm{a} 2 . \mathrm{htm}$ ?s_cid=mm6 218a2_w. Accessed 05/12/ 2015.

11. Centers for Disease Control and Prevention (CDC). (2010). National chronic kidney disease fact sheet: General information and national estimates on chronic kidney disease in the United States, 2010. Atlanta, GA: U.S. Department of Health and Human Services, Centers for Disease Control and Prevention.

12. Centers for Disease Control and Prevention (CDC). (2011). National diabetes fact sheet: National estimates and general information on diabetes and prediabetes in the United States, 2011. Atlanta, GA: U.S. Department of Health and Human Services, Centers for Disease Control and Prevention.

13. Centers for Disease Control and Prevention, National Center for Health Statistics. Underlying Cause of Death 1999-2013 on CDC WONDER Online Database (2015). Data are from the Multiple Cause of Death Files, 1999-2013, as compiled from data provided by the 57 vital statistics jurisdictions through the Vital Statistics Cooperative Program. Available from: http://wonder.cdc.gov/ucd-icd10.html. Accessed on 05/12/15.

14. De Boer, R. A., loannou, G. N., Kestenbaum, B., Brunzell, J. D., and Weiss, N. S. (2007). 25-hydroxyvitamin D levels and albuminuria in the Third National Health and Nutrition Examination survey (NHANES III). American Journal of Kidney Diseases, 50(1):69-77.

15. De Boer, R. A., Katz, R., Chonchol, M., et al. (2011). Serum 25hydroxyvitamin $\mathrm{D}$ and change in estimated glomerular filtration rate. Clinical Journal of the American Society of Nephrology, 6(9):2141-2149.

16. de Zeeuw, D., Agarwal, R., Amdahl, M., et al. (2010). Selective vitamin D receptor activation with paricalcitol for reduction of albuminuria in patients with type 2 diabetes (VITAL study): A randomised controlled trial. Lancet, 376:1543-1551.

17. Diaz, V. A., Mainous, A.G. 3rd, Carek, P. J., Wessell, A. M., and Everett, C. J. (2009). The association of vitamin D deficiency and insufficiency with diabetic nephropathy: Implications for health disparities. Journal of the American Board of Family Medicine, 22:521-527.

18. Fishbane, S., Chittinen, H., Packman, M., et al. (2009). Oral paricalcitol in the treatment of patients with CKD and proteinuria: A randomized trial. American Journal of Kidney Diseases, 54:647-652. 
19. Forman, J. P., Giovannucci, E., Holmes, M.D., et al. (2007). Plasma 25hydroxyvitamin $D$ levels and risk of incident hypertension. Hypertension, 49(5):1063-1069. doi: 10.1161/HYPERTENSIONAHA.107.087288.

20. Forman, J. P., Scott, J. B., Ng, K., et al. (2013). Effect of vitamin D supplementation on blood pressure in Blacks. Hypertension, 61(4):779785. doi: 10.1161/HYPERTENSIONAHA.111.00659.

21. Garcia-Lopes, M. G., Pillar, R., Kamimura, M. A, et al. (2012). Cholecalciferol supplementation in chronic kidney disease: Restoration of vitamin D status and impact on parathyroid hormone. Annals of Nutrition and Metabolism, 61:74-82.

22. Heaney, R. P., Recker, R. R., Grote, J., Horst, R. L., and Armas, L. A. (2011). Vitamin $D(3)$ is more potent than vitamin $D(2)$ in humans. The Journal of Clinical Endocrinology \& Metabolism, 96:E447-452.

23. Heaney, R. P. (2005). The vitamin D requirement in health and disease. The Journal of Steroid Biochemistry and Molecular Biology, 97:13-19.

24. Houghton, L. A., and Vieth, R. (2006). The case against ergocalciferol (vitamin D2) as a vitamin supplement. The American Journal of Clinical Nutrition, 84(4):694-697.

25. Inker, L. A., Schmid, C. H., Tighiouart, H., et al. (2012). Estimating glomerular filtration rate from serum creatinine and cystatin $\mathrm{C}$. The New England Journal of Medicine, 5;367(1):20-29.

26. Institutes of Medicine. (2010). DRI tables. Available from: http://fnic.nal.usda.gov/dietary-guidance/dietary-reference-intakes/dritables. Accessed 01/24/ 2015.

27. Isakova, T., Gutiérrez, O. M., Patel, N. M., et al. (2011). Vitamin D deficiency, inflammation, and albuminuria in chronic kidney disease: complex interactions. Journal of Renal Nutrition, 21(4):295-302. doi: 10.1053/j.jrn.2010.07.002.

28. Jorde, R., Sneve, M., Torjesen, P., and Figenschau, Y. (2010). No improvement in cardiovascular risk factors in overweight and obese subjects after supplementation with vitamin D3 for 1 year. Journal of Internal Medicine, 267(5):462-472. doi: 10.1111/j.13652796.2009.02181.x.

29. Judd, S., and Tangpricha, V. (2008). Vitamin D deficiency and risk for cardiovascular disease. Circulation, 29(117):503-511. 
30. Kandula, P., Dobre, M., Schold, J. D., et al. (2011). Vitamin D supplementation in chronic kidney disease: A systematic review and metaanalysis of observational studies and randomized controlled trials. Clinical Journal of the American Society of Nephrology, 6:50-82.

31. KDOQI Clinical Practice Guidelines for Chronic Kidney Disease: Evaluation, Classification, and Stratification. Part 5. Evaluation of laboratory measurements for clinical assessment of kidney disease. (2000). Available from:

http://www.kidney.org/professionals/kdoqi/guidelines ckd/p5 lab g5.htm.. Accessed 03/12/ 2015.

32. Kim, M. J., Frankel, A. H., Donaldson, M., et al. (2011). Oral cholecalciferol decreases albuminuria and urinary TGF-beta1 in patients with type 2 diabetic nephropathy on established renin-angiotensinaldosterone system inhibition. Kidney International, 80:851-860.

33. Larsen, T., Mose, F. H., Bech, J. N., Hansen, A. B., and Pedersen, E. B. (2012). Effect of cholecalciferol supplementation during winter months in patients with hypertension: a randomized, placebo-controlled trial. American Journal of Hypertension, 25(11):1215-1222. doi: 10.1038/ajh.2012.111.

34. Lee, Y. M., Parks, S. W., Kim, J. S., et al. (2010). 25-hydroxyvitamin D status in patients with chronic kidney disease in a single center. Korean Journal of Nephrology, 29:458-464.

35. Levey, A. S., Stevens, L. A., Schmid, C. H., et al. (2009). A new equation to estimate glomerular filtration rate. Annals of Internal Medicine, 5;150(9):604-612.

36. Li, Y. (2012). Vitamin D: Roles in renal and cardiovascular protection. Current Opinion in Nephrology and Hypertension, 21(1):72-79.

37. Li, Y. C., Qiao, G., Uskokovic, M., et al. (2004). Vitamin D: a negative endocrine regulator of the renin-angiotensin system and blood pressure. The Journal of Steroid Biochemistry and Molecular Biology, 89-90(15):387-392.

38. Melamed, M. L., Astor, B., Michos, E. D., et al. (2009). 25-hydroxyvitamin $\mathrm{D}$ levels, race, and the progression of kidney disease. Journal of the American Society of Nephrology, 20(12):2631-2639.

39. Moe, S. M., Saifullah, A., LaClair, R. E., Usman, S. A., and Yu, Z. (2010). A randomized trial of cholecalciferol versus doxercalciferol for lowering parathyroid hormone in chronic kidney disease. Clinical Journal of the 
American Society of Nephrology, 5(2):299-306. doi:

10.2215/CJN.07131009.

40. Mogensen, C.E. (1984). Microalbuminuria predicts clinical proteinuria and early mortality in maturity-onset diabetes. The New England Journal of Medicine, 310(6):356-360.

41. Molina, P., Gorriz, J. L., Molin, M. D., et al. (2014). The effect of cholecalciferol for lowering albuminuria in chronic kidney disease: $\mathrm{A}$ prospective controlled study. Nephrology Dialysis Transplantation, 29(1):97-109. doi:10.1093/ndt/gft360.

42. Nasri, H., Behradmanesh, S., Ahmadi, A., and Rafieian-Kopaei, M. (2014). Impact of oral vitamin $\mathrm{D}$ (cholecalciferol) replacement therapy on blood pressure in type 2 diabetes patients; a randomized, double-blind, placebo controlled clinical trial. Journal of Nephropathology, 3(1):29-33. doi: 10.12860/jnp.2014.07.

43. National Center for Health Statistics. (2012). National vital statistic reports, 10:61(6).

44. National Kidney Foundation. (2009). Cystatin C: What is the role in estimating GFR? Available from:

https://www.kidney.org/sites/default/files/02-10-0204_GAJ_CystatinC.pdf. Accessed 06/12/ 2015.

45. National Kidney Foundation. (2003). K/DOQI Clinical Practice Guidelines for Bone Metabolism and Disease in Chronic Kidney Disease. American Journal of Kidney Diseases, $42(4$ Suppl 3):S1-201.

46. Nwankwo, T., Yoon, S. S., Burt, V., and Gu, Q. (2013). Hypertension among adults in the US: National Health and Nutrition Examination Survey, 2011-2012. NCHS Data Brief, No. 133. Hyattsville, MD: National Center for Health Statistics, Centers for Disease Control and Prevention, US Department of Health and Human Services.

47. Pfeifer, M., Begerow, B., Minne, H. W., Nachtigall, D., and Hansen, C. (2001). Effects of a short-term vitamin D(3) and calcium supplementation on blood pressure and parathyroid hormone levels in elderly women. The Journal of Clinical Endocrinology \& Metabolism, 86(4):1633-1637.

48. Pilz, S., Tomaschitz, A., Ritz, E., Pieber, T. R. (2009). Vitamin D status and arterial hypertension: a systematic review. Nature Reviews Cardiology, 6(10):621-630. doi: 10.1038/nrcardio.2009.135. 
49. Pittas, A. G., Chung, M., Trikalinos, T, et al. (2010). Systematic review: Vitamin D and cardiometabolic outcomes. Annals of Internal Medicine, 2;152(5):307-314. doi: 10.7326/0003-4819-152-5-201003020-00009.

50. Rucker, D., Tonelli, M., Coles, M. G., et al. (2009). Vitamin D insufficiency and treatment with oral vitamin D3 in northern-dwelling patients with chronic kidney disease. Journal of Nephrology, 2:75-82.

51. Schmitz, K. J., Skinner, H. G., Bautista, L. E., et al. (2009). Association of 25-hydroxyvitamin $\mathrm{D}$ with blood pressure in predominantly 25hydroxyvitamin D deficient Hispanic and African Americans. American Journal of Hypertension, 22(8):867-870. doi: 10.1038/ajh.2009.88.

52. Scragg, R., Khaw, K. T., and Murphy, S. (1995). Effect of winter oral vitamin D3 supplementation on cardiovascular risk factors in elderly adults. The European Journal of Clinical Nutrition, 49(9):640-646.

53. Scragg, R., Sowers, M., and Bell, C. (2007). Serum 25-hydroxyvitamin D, ethnicity, and blood pressure in the Third National Health and Nutrition Examination Survey. American Journal of Hypertension, 20(7):713-719.

54. Skaaby, T., Husemoen, L. L., Pisinger, D., et al. (2013). Vitamin D status and 5-year change in urine albumin creatinine ratio and parathyroid hormone in a general population. Endocrine, 44(2):473-480. doi: 10.1007/s12020-013-9887-0.

55. Sugden, J. A., Davies, J. I., Witham, M. D., Morris, A. D., and Struthers, A. D. (2008). Vitamin D improves endothelial function in patients with Type 2 diabetes mellitus and low vitamin D levels. Diabetic Medicine, 25(3):320325. doi: 10.1111/j.1464-5491.2007.02360.x.

56. Williams, S., Malatesta, K., and Norris, K. (2009). Vitamin D and chronic kidney disease. Ethnicity \& Disease, 19(4):S5-8-11.

57. Witham, M. D., Dove, F. J., Dryburgh, M., et al. (2010). The effect of different doses of vitamin $\mathrm{D}(3)$ on markers of vascular health in patients with type 2 diabetes: a randomised controlled trial. Diabetologia, 53(10):2112-2119. doi: 10.1007/s00125-010-1838-1.

58. Witham, M. D., Nadir, M. A., and Struthers, A. D. (2009). Effect of vitamin $D$ on blood pressure: a systematic review and meta-analysis. Journal of Hypertension, 27(10):1948-1954. doi: 10.1097/HJH.0b013e32832f075b.

59.Zadshir, A., Tareen, N., Pan, D., Norris, K., and Martins, D. (2005). The prevalence of hypovitaminosis $D$ among US adults: Data from the NHANES III. Ethnicity \& Disease, 15(S5):97-101. 
60.Zimmermann, A., and Gummert, J. F. (2010). Nonclassical vitamin D action. Nutrients, 2:408-425. 
Appendix 1: Consent Forms 


\title{
FIU]
}

\author{
ADULT CONSENT TO PARTICIPATE IN A RESEARCH STUDY \\ "The Effect of Vitamin D Supplementation on Cardiovascular Risk Factors among Hispanics and \\ African Americans with Type 2 diabetes"
}

\section{PURPOSE OF THE STUDY}

You are being asked to participate in a research study. The purpose of this study is to determine the effect of supplemental vitamin D intake on cardiovascular risk factors in Hispanics and African Americans with type 2 diabetes.

\section{NUMBER OF STUDY PARTICIPANTS}

If you decide to be in this study, you will be one of 120 people in this research study.

\section{DURATION OF THE STUDY}

Your participation will require one (1) visit every 3 months and each visit may last up to 3 hours. You will be asked to participate in an initial blood collection screening. Depending on your vitamin D level, you will be contacted either to continue in the study or you will be told that you do not qualify after your first visit. If you qualify for the study, you will be required to make a total of 4 visits to the human nutrition lab, during the study period.

\section{PROCEDURES}

If you agree to be in the study, the following procedures will be done:

1. You will provide information on your gender, age, level of education, year of diagnosis of diabetes, medication use, and smoking.

2. You will answer questions about your mood, sun exposure habits and dietary intakes.

3. Your skin color will be measured by a hand-held device. This will be painless.

4. A certified phlebotomist will draw your blood (approximately four tablespoons of blood or $15 \mathrm{ml}$ ). Blood will be drawn from your arm. You will also provide a urine sample.

5. You will be required to take Vitamin D at a dose of $4000 \mathrm{IU} /$ day or $6000 \mathrm{IU} /$ day for 6 months.

6. You will take $4000 \mathrm{IU} /$ day if you are one of the first 60 participants and $6000 \mathrm{IU} /$ day if you are among the next 60 participants.

\section{RISKS AND/OR DISCOMFORTS}

The following risks may be associated with your participation in this study: First, soreness, redness or possible infection of the area in front of elbow joint from where blood will be drawn. A certified phlebotomist will be using sterile and standard procedures. Therefore, risks of soreness, redness or infection may be extremely rare. Second, you may experience very mild dizziness that is reversible within few minutes without any effects. Taking high doses of Vitamin D may cause signs of toxicity such as nausea, vomiting, excess thirst, excess urination, weakness and nervousness. You will be required to immediately report to the PI or the study team if you experience any of these issues. Study team will regularly monitor you at all visits for signs of toxicity. If you show signs of toxicity due to vitamin D, you will be withdrawn from the study. 


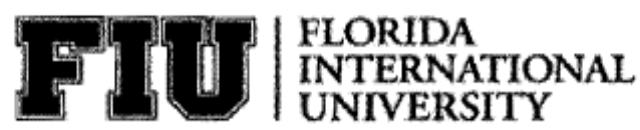

\section{BENEFITS}

The following benefits may be associated with your participation in this study:

- You will receive your blood test, diet analysis results and be able to ask questions about Diabetes and the study.

- Vitamin D may improve your bone density.

\section{ALTERNATIVES}

You may choose not to participate in the study or withdraw from the study at anytime without any consequences.

\section{CONFIDENTIALITY}

The records of this study will be kept private and will be protected to the fullest extent provided by law. In any sort of report we might publish, we will not include any information that will make it possible to identify a subject. Research records will be stored securely and only the research team will have access to the records. The U.S. Department of Health and Human Services (DHHS) and/or the Food and Drug Administration (FDA) may request copies of your records to review them. Your records may also be reviewed for audit purposes by authorized University or other agents who will be bound by the same provisions of confidentiality. A description of this clinical trial will be available on http://www.ClinicalTrials.gov, as required by US Law. This web site will not include information that can identify you. At most, the web site will include a summary of the results. You can search this website at anytime.

\section{COMPENSATION \& COSTS}

You will receive a payment of twenty (\$20) dollars for your participation on the first visit. If you qualify for the study, you will receive a payment of twenty (\$20) dollars on your second visit and forty $(\$ 40)$ dollars each on the third and fourth visit. You will not be responsible for any costs to participate in this study.

\section{MEDICAL TREATMENT}

Routinely, FIU, its agents, or its employees do not compensate for or provide free care for human subjects in the event that any injury results from participation in a research project. If you become ill or injured as a direct result of participating in this study, contact your regular medical provider. If you have insurance, your insurance company may or may not pay for these costs. If you do not have insurance, or if your insurance company refuses to pay, you will be billed. Funds to compensate for pain, expenses, lost wages and other damages caused by injury are not routinely available. If you show symptoms of physical or mental illness, you will be referred to your physician with your permission.

\section{RIGHT TO DECLINE OR WITHDRAW}

Your participation in this study is voluntary. You are free to participate in the study or withdraw your consent at any time during the study. Your withdrawal or lack of participation will not affect any benefits to which you are otherwise entitled. The investigator reserves the right to withdraw you from the study without your consent at such time that they feel is in the best interest of the study participant. 


\section{FIU]}

\section{RESEARCHER CONTACT INFORMATION}

If you have any questions about the purpose, procedures, or any other issues relating to this research study you may contact Dr. Fatma G. Huffman at HLS I room 435, (305) 348-3788, huffmanf@fiu.edu.

\section{IRB CONTACT INFORMATION}

If you would like to talk with someone about your rights of being a subject in this research study or about ethical issues with this research study you may contact Dr. Patricia Price, the Chairperson of the FIU Institutional Review Board (IRB) at 305-348-2618 or 305-348-2494.

\section{PARTICIPANT AGREEMENT}

I have read the information in this consent form and agree to participate in this study. I have had a chance to ask any questions I have about this study, and they have been answered for me. I understand that I am entitled to a copy of this form after it has been read and signed.

Signature of Participant

Printed Name of Participant

Signature of Person Obtaining Consent
Date

Date 


\section{FTU}

\section{CONSENTIMIENTO PARA PARTICIPAR EN UN ESTUDIO DE INVESTIGACION \\ "El Efecto de la Suplementación con Vitamina D en los Factores de Riesgo de Enfermedad Cardiovascular en Hispanos y Afro-Americanos con Diabetes Tipo 2"}

\section{PROPOSITO DEL ESTUDIO}

Usted ha sido invitado para participar en un estudio de investigación. El propósito del estudio es determinar el efecto de la suplementación con vitamina D en factores de riesgo cardiovasculares en Hispanos y AfroAmericanos con diabetes tipo 2.

\section{NUMERO DE PARTICIPANTES EN EL ESTUDIO}

Si usted participa en este estudio, será una de las 120 personas en este estudio de investigación.

\section{DURACION DEL ESTUDIO}

Su participación requerirá una (1) visita cada 3 meses y duraran alrededor de 3 horas cada una. Usted proveerá una muestra de sangre para selección. Dependiendo de sus niveles de vitamina D en sangre usted será contactado para continuar en el estudio o será retirado del mismo. Si usted califica para el estudio, usted tendrá que hacer un total de 4 visitas al laboratorio de nutrición humana.

\section{PROCEDIMIENTOS}

Si usted acepta participar en este estudio, los siguientes procedimientos serán realizados:

1. Usted proveerá información sobre su género, edad, nivel educacional, año de diagnostico de diabetes, medicación usada, y habito de fumar;

2. Usted responderá preguntas sobre sus sentimientos, hábitos de exposición al sol e ingesta de alimentos;

3. Su color de piel será medido por un instrumento manual. Esto será indoloro;

4. Un flebotomista certificado le sacara sangre (aproximadamente 4 cucharadas de sangre o $15 \mathrm{ml}$ ). La sangre será obtenida de su brazo. Usted proveerá una muestra de orina

5. Usted tendrá que tomar $4000 \mathrm{IU}$ o $6000 \mathrm{IU}$ de vitamina $\mathrm{D}$ al día por 6 meses.

6. Usted tomara $4000 \mathrm{UI} /$ dia si usted es uno de los 60 primeros participantes y $6000 \mathrm{UI} /$ dia is usted esta dentro de los siguientes 60 participantes.

\section{RIESGOS Y/O MOLESTIAS}

Los siguientes riesgos pueden ser asociados con su participación en el estudio: primero, dolor, enrojecimiento o posible infección del área enfrente del codo de donde la sangre fue obtenida. Un flebotomista certificado usara procedimientos estériles y estándares, por lo tanto, el riesgo de dolor, enrojecimiento o infección es muy raro. Segundo, usted puede experimentar un ligero mareo, el cual desaparecerá en unos pocos minutos sin ningún efecto. Tomar altas dosis de vitamina $\mathrm{D}$ puede causar síntomas de intoxicación como nausea, vomito, excesiva sed, excesiva micción, debilidad y nerviosismo. Usted tendrá que reportarse inmediatamente al PI o al equipo de investigación si usted sufriera de alguno de estos síntomas. El equipo de investigación estará constantemente monitoreando algún signo de intoxicación que usted presente. Si usted presenta signos de intoxicación causados por la vitamina $\mathrm{D}$, usted podría ser retirado del estudio.

\section{BENEFICIOS}

Los siguientes beneficios pueden ser asociados con su participación en este estudio:

- Usted recibirá los resultados de su análisis de sangre, dieta y podrá hacer preguntas referentes a la diabetes.

- La vitamina D puede mejorar su densidad ósea 


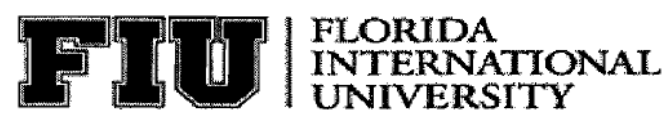

\begin{abstract}
ALTERNATIVAS
Usted puede escoger no participar en el estudio o retirarse del estudio en cualquier momento sin ninguna consecuencia.
\end{abstract}

\title{
CONFIDENCIALIDAD
}

Los archivos de este estudio serán privados y protegidos por la ley. En cualquier reporte que nosotros publiquemos, no incluiremos ninguna información que haga posible identificar a un sujeto. Los archivos serán guardados en forma asegura y solo el equipo de investigación tendrá acceso a ellos. El Departamento de Salud y Servicios Humanos de los Estados Unidos (DHHS) y/o la Administración de Alimentos y Drogas (FDA) pueden pedir copias de sus archivos para revisarlos. Sus archivos pueden ser también revisados para propósitos de auditoría por agentes autorizados de la Universidad u otros agentes que seguirán las mismas reglas de confidencialidad. Una descripción de este estudio clínico estará disponible en http://www.ClinicalTrials.gov, según lo requiere la ley. Esta página web no incluirá información que lo pueda identificar. A lo sumo, la página web incluirá un resumen de los resultados. Usted puede acceder a esta página web en cualquier momento.

\section{COMPENSACION Y COSTOS}

Usted recibirá un pago de veinte $(\$ 20)$ dólares por su participación en la primera visita. Si usted califica para el resto del estudio, recibirá un pago de veinte $(\$ 20)$ dólares en su segunda visita y cuarenta $(\$ 40)$ dólares por la tercera y cuarta visita. Usted no será responsable de ningún costo por participar en este estudio.

\section{TRATAMIENTO MEDICO}

Rutinariamente, FIU, sus agentes, o sus empleados no compensan o proveen cuidado gratis a sujetos en el evento de que una lesión resulte de su participación en el proyecto de investigación. Si usted resulta enfermo o lesionado como resultado directo de su participación en el estudio, contacte a su médico. Si usted tiene seguro, su compañía de seguros puede o no pagar por estos costos. Si usted no tiene seguro, o si su compañía de seguros se niega a pagar, usted será facturado. Fondos para compensar por dolor, gastos, pérdida de salario y otros daños causados por lesión no están disponibles habitualmente. Si usted muestra síntomas de enfermedad física o mental, será referido a su médico con su consentimiento.

\section{DERECHO DE DECLINAR O RETIRARSE}

$\mathrm{Su}$ participación en el estudio es voluntaria. Usted es libre de participar en el estudio o de retirar su consentimiento en cualquier momento durante el estudio. Su retiro o falta de participación no afectara ningún beneficio para los cuales tenga derecho. Los investigadores se reservan el derecho de removerlo del estudio sin su consentimiento en el momento que ellos lo crean necesario.

\section{INFORMACION DE CONTACTO DEL INVESTIGADOR}

Si tiene alguna pregunta acerca del propósito, procedimiento, u otro tema relacionado a esta investigación, puede contactar a Dr: Fatma G. Huffman en HLS I oficina 435, (305) 348-3788, huffmanf@fiu.edu.

\section{INFORMACION DE CONTACTO DEL IRB}

Si usted desea hablar con alguien acerca de sus derechos como participante en este estudio o acerca de temas éticos relacionados con el estudio, puede contactar a Dr. Patricia Price, Directora del Comité de Revisión Institucional de la FIU (IRB) al 305-348-2618 o 305-348-2494. 


\section{FiIII|}

\section{ACUERDO DEL PARTICIPANTE}

Yo he leído la información en esta forma de consentimiento y estoy de acuerdo en participar en el estudio. Yo he tenido la opción de hacer preguntas acerca del estudio y han sido respondidas. Yo entiendo que tengo derecho a una copia de esta forma después de haberla leído y firmado.

Firma del Participante

Nombre del Participante

Firma de la Persona que Obtiene el Consentimiento
Fecha

\author{
Fecha
}


Appendix 2: Short Food Frequency Questionnaire 


\section{Short Food Frequency Questionnaire Visit___ Date___ ID\#}

This form asks about your usual eating habits over the past year.

First: For each food listed, mark the column to show how often, on average, you ate the food during the past year.

Please BE CAREFUL which column you put your answer in.

Second: Mark whether your usual serving size is small, medium, or large. Please DO NOT OMIT serving size.

Additional Comments:

Please DO NOT SKIP any foods, if you never eat a food, mark "Never or less that once per month."

A small serving is one-half the medium serving size shown or less.

A large serving is about one-and-a-half times the medium serving size shown or more.

Sample: This person ate a medium serving of rice about twice per month and never ate squash.

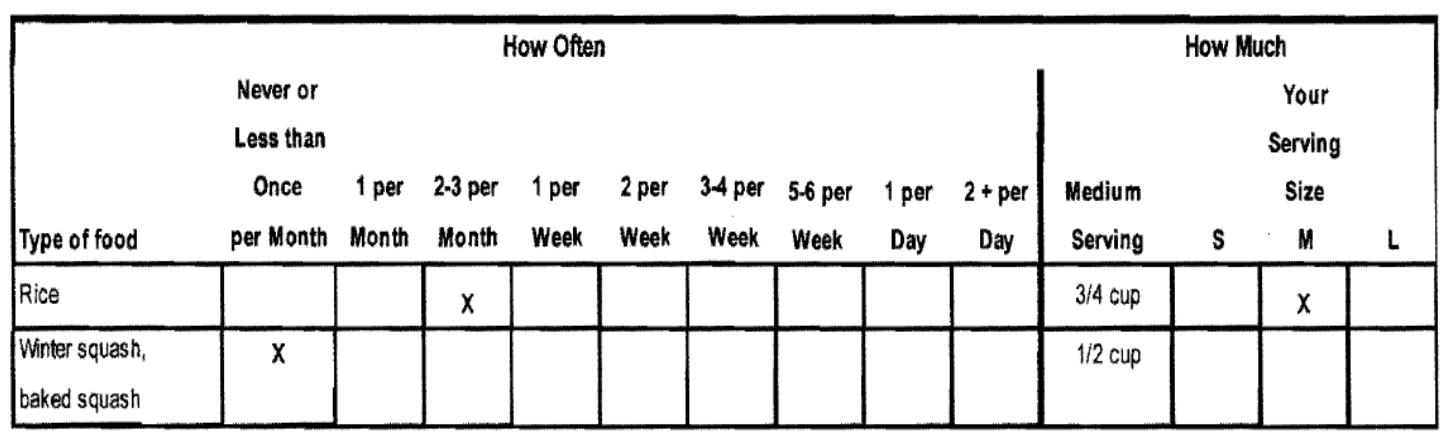

\begin{tabular}{|c|c|c|c|c|c|c|c|c|c|c|c|c|c|}
\hline \multirow[b]{2}{*}{ Type of Beverage } & $\begin{array}{l}\text { Never or } \\
\text { Less than } \\
\text { Once }\end{array}$ & 1 per & $2 \cdot 3 \mathrm{per}$ & ow Ofte & 2 per & $3-4$ per & $5.6 \mathrm{per}$ & 1 per & 2.3 per & Medium & low 1 & $\begin{array}{l}\text { ch } \\
\text { Your } \\
\text { Serving } \\
\text { Size }\end{array}$ & \\
\hline & per Month & Month & Month & Week & Week & Week & Week & Day & Day & Serving & $s$ & M & L \\
\hline $\begin{array}{l}\text { Whole milk and } \\
\text { beverages with } \\
\text { whole milk (not } \\
\text { including cereals) }\end{array}$ & & & & & & & & & & $80 z$ glass & & & \\
\hline $\begin{array}{l}2 \% \text { milk and } \\
\text { beverage } \\
\text { With 2\% milk (not } \\
\text { including cereal) }\end{array}$ & & & & & & & & & & 802 glass & & & \\
\hline $\begin{array}{l}\text { Skim milk, } 1 \% \text { milk } \\
\text { or buttermilik (not } \\
\text { including on cereal) }\end{array}$ & & & & & & & & & & 8 oz glass & & & \\
\hline Milk in coffee or tea & & & & & & & & & & 1 tablespoon & & & \\
\hline
\end{tabular}




\begin{tabular}{|c|c|c|c|c|c|c|c|c|c|c|c|c|c|}
\hline Type of food & $\begin{array}{l}\text { Never or } \\
\text { Less than } \\
\text { Once } \\
\text { per Month }\end{array}$ & $\begin{array}{l}1 \text { per } \\
\text { Month }\end{array}$ & $\begin{array}{l}2-3 \text { per } \\
\text { Month }\end{array}$ & $\begin{array}{l}1 \text { per } \\
\text { Week }\end{array}$ & $\begin{array}{l}2 \text { per } \\
\text { Week }\end{array}$ & $\begin{array}{l}\text { 3-4 per } \\
\text { Week }\end{array}$ & $\begin{array}{l}\text { 5.6 per } \\
\text { Week }\end{array}$ & $\begin{array}{l}1 \text { per } \\
\text { Day }\end{array}$ & $\begin{array}{c}2+\text { per } \\
\text { Day }\end{array}$ & $\begin{array}{l}\text { Medium } \\
\text { Serving }\end{array}$ & ow I & $\begin{array}{l}\text { Your } \\
\text { Size } \\
\text { M }\end{array}$ & L \\
\hline Broccoll & & & & & & & & & & $1 / 2$ cup & & & \\
\hline $\begin{array}{l}\text { Mustard greens, } \\
\text { turnip greens, } \\
\text { collard greens }\end{array}$ & & & & & & & & & & $1 / 2$ cup & & & \\
\hline $\begin{array}{l}\text { Spaghetti, } \\
\text { lasagna, other } \\
\text { pasta with } \\
\text { tomato sauce }\end{array}$ & & & & & & & & & & 1 cup & & & \\
\hline $\begin{array}{l}\text { Mixed dishes with } \\
\text { cheese (such as } \\
\text { macaroni and } \\
\text { cheese) }\end{array}$ & & & & & & & & & & 1 cup & & & \\
\hline $\begin{array}{l}\text { Cheese and } \\
\text { cheese spreads } \\
\text { (including on } \\
\text { sandwiches, } \\
\text { burgers, tacos, } \\
\text { and nachos; } \\
\text { not including } \\
\text { cottage cheese) }\end{array}$ & & & & & & & & & & $\begin{array}{c}2 \text { slices } \\
\text { or } \\
2 \mathrm{oz}\end{array}$ & & & \\
\hline $\begin{array}{l}\text { White bread } \\
\text { (including } \\
\text { sandwiches, } \\
\text { bagels, burger } \\
\text { rolls, French or } \\
\text { Italian bread) }\end{array}$ & & & & & & & & & & 2 slices & & & \\
\hline $\begin{array}{l}\text { Dark bread, } \\
\text { such as wheat, } \\
\text { rye, pumper- } \\
\text { nickel fincluding } \\
\text { sandwiches) }\end{array}$ & & & & & & & & & & 2 slices & & & \\
\hline $\begin{array}{l}\text { Biscuits or } \\
\text { muffins } \\
\text { (including } \\
\text { fast foods) }\end{array}$ & & & & & & & & & & $\begin{array}{c}1 \text { medium } \\
\text { piece }\end{array}$ & & & \\
\hline lce cream & & & & & & & & & & $\begin{array}{c}1 \text { scoop or } \\
1 / 2 \text { cup }\end{array}$ & & & \\
\hline $\begin{array}{l}\text { Yogurt, frozen } \\
\text { yogurt }\end{array}$ & & & & & & & & & & 1 cup & & & \\
\hline Milk on cereal & & & & & & & & & & 1/2 cup & & & \\
\hline
\end{tabular}




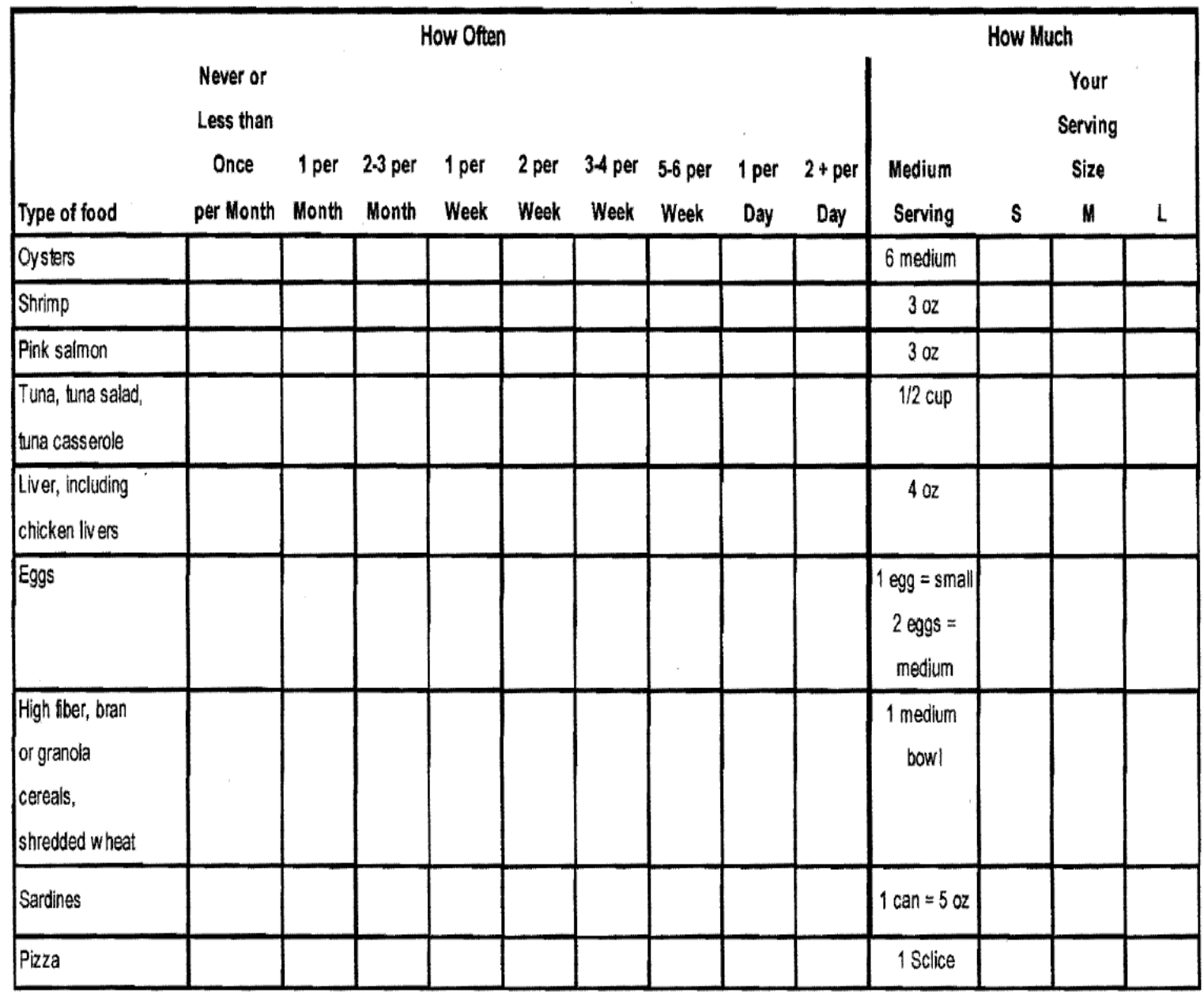


Appendix 3: Skin Color and Anthropometrics Control Form 
ID \#.

Date:

\title{
Anthropometrics, Blood Pressure \& skin color (screening/baseline/3months/6months)
}

\begin{abstract}
Weight:
pounds

Height: inches

BMI:
\end{abstract}

Waist circumference 1

.cms

Waist circumference 2 cms

Average Waist Circumference: .cms

\section{Blood Pressure 1:}

Systolic $\mathrm{mm} \mathrm{Hg}$

Diastolic. $\mathrm{mm} \mathrm{Hg}$

\section{Blood Pressure 2:}

Systolic $\mathrm{mm} \mathrm{Hg}$

Diastolic $\mathrm{mm} \mathrm{Hg}$

Average Blood Pressures:

Average Systolic: $\mathrm{mm} \mathrm{Hg}$

Average Diastolic: mm Hg $\underline{\text { Skin color 1: }}$

Forearm:

Upper arm:

Stomach:

Skin color 2:

Forearm:

Upper arm:

Stomach:

Average Skin Color:

Forearm:

Upper arm:

Stomach:

Average difference: 
Appendix 4: Demographic Questionnaire 


\section{Demographic Questionnaire}

Date

ID\#

Please answer each of the questions by filling in the blanks with the correct answer or by choosing the single best answer.

Q1. Please indicate your age in years

Q2. Male $\square_{1} \quad$ Female $\square_{2}$

Q3. How much schooling did you have?

$\square$ 1. $\quad 8^{\text {th }}$ grade or less

$\square$ 2. Some high school

$\square$ 3. High school diploma or GED

$\square$ 4. At least some college

Q4. Do you use tobacco? No $\square_{1}$ Yes $\square_{2}$

Q4a. Please indicate your tobacco use

$\square$. Cigarettes $\square_{2}$ Cigar $\square_{3}$ Pipe $\quad \square_{4}$ Chewing

Q4b. How many cigarettes do you smoke each day on average?

$\square 1 \quad 1-6 \quad \square_{2} \quad 7-12 \quad \square$ 3 13 or more

Q5. How many drinks of alcohol ( 12 oz beer, 5 oz wine, 1 oz hard liquor) do you drink each week on average?

$\square 1$ None $\square_{2} \quad 1-2 \quad \square_{3} \quad 3-7 \quad \square_{4} \quad$ 8-14 $\square_{5} \quad 15-21 \quad \square 6 \quad 22$ or more

Q6. Please indicate any of the following types of medications that you take

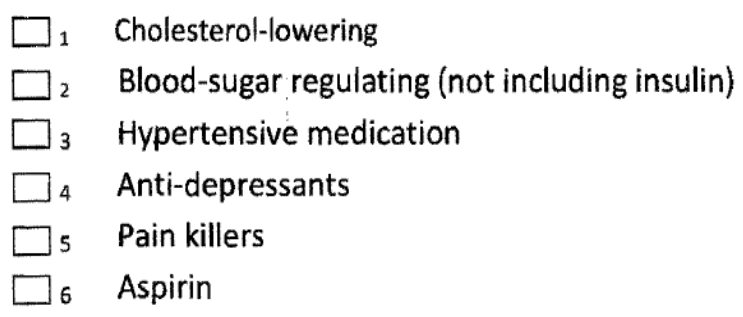

Q7. What year were you first diagnosed with diabetes? $19 . . . . . . . . . . . .$.

Q8. What is your marital status? $\square$ 1 Married $\square_{2}$ Single $\square_{3}$ Divorced $\square_{4}$ Widowed

Q9. Do you currently have a job? $\square$ 1 No $\square_{2}$ Yes $\square_{3}$ I am disabled

Q10. How many years have you been living in the US?

Q11. Do you currently have health insurance? $\quad \square 1$ No $\quad \square_{2}$ Yes 
Appendix 5: Compliance and Adverse Events Form 
3 months visit date:

Type of visit: 3 months

Baseline visit date:

No of days between visits (a):

\section{PILL COUNT}

Pills dispensed during last visit: $\quad$ Number of pills taken (b):

Adherence $b / a$ :

On time $\square \quad$ Late $\square \quad$ Compliant: Yes/ No

\section{Adverse Events Log}

\section{Date of event:}

Date reported to IRB:

Notes about the event:

Remarks/Comments about the visit

Hospitalization: Yes/No

Surgery: Yes/ No

\section{TH MONTH VISIT}

6 months visit date:

3 months visit date:

No of days between visits (a):

PILL COUNT

Pills dispensed during last visit: $\quad$ Number of pills taken (b):

Adherence b/a:

On time $\square \quad$ Late $\square \quad$ Compliant: Yes/ No

Adverse Events Log

Date of event:

Date reported to IRB:

Notes about the event:

Remarks/ Comments about the visit

Hospitalization: Yes/No

Surgery: Yes/ No

Investigator's signature

Investigator's signature 
VITA

GUSTAVO G. ZARINI

Born, Buenos Aires, Argentina

$1997-2001$

B.S., Nutrition

University of Belgrano

Buenos Aires, Argentina

2002-2007

M.S., Dietetics and Nutrition

Florida International University

Miami, Florida

2016-2017

Fellowship Recipient Starr Foundation

Florida International University

Miami, Florida

$2012-2017$

Doctoral Candidate

Florida International University

Miami, Florida

\section{PUBLICATIONS AND PRESENTATIONS}

Exebio, J. C., Zarini, G. G., Ajabshir, S., Antwi, J., and Huffman, F. G. (2016). Validation of a sun exposure questionnaire among subjects with type 2 diabetes residing in South Florida. Journal of Immigrant and Minority Health, 18(1):228233. doi: 10.1007/s10903-015-0163-7.

Cheema, A. K., Li, T., Liuzzi, J. P., Zarini, G. G., Dorak, M. T., and Huffman, F. G. (2015). Genetic associations of ppargc1a with type 2 diabetes: differences among populations with African origins. Journal of Diabetes Research, Article ID 921274, 10 pages. http://dx.doi.org/10.1155/2015/921274.

Cheema, A. K., Li, T., Liuzzi, J. P., Zarini, G. G., and Huffman, F. G. (2015). Peroxisome proliferator-activated receptor gamma coactivator-1 alpha (ppargc1a) polymorphism linked with microalbuminuria in hypertensive Haitian Americans with type 2 diabetes. International Journal of Health Sciences and Research, 5(2):295-303.

Zarini, G. G., Vaccaro, J. A., Canossa Terris, M. A., Exebio, J. C., Tokayer, L., Antwi, J., Ajabshir, S., Cheema, A., and Huffman, F.G. (2014). Lifestyle behaviors and self-rated health: the living for health program. Journal of 
Environmental and Public Health, Volume 2014 (2014), Article ID 315042, 9 pages. http://dx.doi.org/10.1155/2014/315042.

Ajabshir, S., Exebio, J. C., Zarini, G.G., Nayer, A., McLean, M., Shaban, L., and Huffman, F. G. (2014). Skin color and self-reported sun exposure scores are associated with serum 25-hydroxyvitamin $D$ concentrations in a multi-ethnic population living in South Florida. British Journal of Medicine and Medical Research, 4(34):5312-5323.

Cheema, A. K., Zarini, G. G., Exebio, J., Ajabshir, S., Shaban, L., Antwi, J., Vaccaro, J. A., and Huffman, F. G. (2014). Ethnic Differences in Insulin resistance, adiponectin levels and abdominal obesity: Haitian Americans and African Americans with and without type 2 diabetes mellitus. British Journal of Medicine and Medical Research, 4(26):4455-4469.

Exebio, J. C., Ajabshir, S., Zarini, G. G., Vaccaro, J., and Huffman, F. G. (2014). Use of homeostatic model assessment indexes for the identification of metabolic syndrome and insulin resistance among Cuban-Americans: a cross sectional study. British Journal of Medicine and Medical Research, 4(29):4824-4833.

Vaccaro, J. A., Exebio, J. C., Zarini, G. G., and Huffman, F. G. (2014). The role of family/friend social support in diabetes self-management for minorities with type 2 diabetes. Journal of Nutrition and Health, 2(1), pp 1-9.

doi: 10.12691/jnh-2-1-1.

Sukhram, S. D., Zarini, G. G., Shaban, L. H., Vaccaro, J. A., and Huffman, F. G. (2014). Obesity and serum high sensitivity c-reactive protein levels among elderly Turkish immigrants in the Netherlands with type 2 diabetes. Ageing International, 39:68-80. doi: 10.1007/s12126-012-9149-0.

Huffman, F. G., Vaccaro, J. A., Zarini, G. G., and Dixon, Z. Comparison of two indices of diet quality with acculturation factors and demographics in Haitian Americans. Ecology of Food and Nutrition, 53:42-57. doi: 10.1080/03670244.2013.774674.

Huffman, F. G., Exebio, J. C., Vaccaro, J. A., Zarini, G. G., and Dixon, Z. (2013). Effect of medical advice for diet on diabetes self-management and glycemic control for Haitian and African Americans with type 2 diabetes. Food and Nutrition Sciences, Vol.4 No.11, Article ID: 37541,8 pages.

doi:10.4236/fns.2013.411142.

Huffman, F. G., Vallasciani, M., Vaccaro, J. A., Exebio, J. C., Zarini, G. G., Nayer, A., and Ajabshir, S. (2013). The association of depression and perceived stress with beta cell function between African and Haitian Americans with and without type 2 diabetes. Journal of Diabetes Mellitus, 3(4):236-243. 